\title{
FIFTH AMENDMENT FIRST PRINCIPLES: THE SELF-INCRIMINATION CLAUSE
}

\author{
Akhil Reed Amar* \\ and Renée B. Lettow**
}

TABLE of Contents

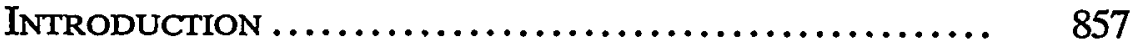

I. The Puzzle ................................... 860

A. "Person"? .................................... 861

B. "Compelled"? .............................. 865

C. "In Any Criminal Case"? .................... 874

D. "Witness"? .................................... 883

E. What's the Big Idea? ........................ 889

II. The Solution ............................... 898

A. "Person" .................................. 901

B. "Compelled" ................................... 904

C. "In Any Criminal Case"....................... 909

D. "Witness" ................................... 919

E. The Big Idea $(s) \ldots \ldots \ldots \ldots \ldots \ldots \ldots \ldots \ldots \ldots \ldots, \quad 922$

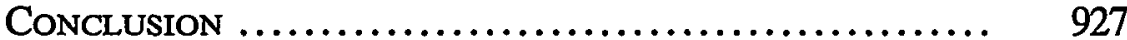

\section{INTRODUCTION}

No person ... shall be compelled in any criminal case to be a witness against himself .... 1

The Self-Incrimination Clause of the Fifth Amendment is an unsolved riddle of vast proportions, a Gordian knot in the middle of our Bill of Rights. From the beginning it lacked an easily identifiable rationale; in 1789 , the words of the clause were more a slogan than a clearly defined legal rule, and in the preceding four centuries

* Southmayd Professor, Yale Law School. B.A. 1980, J.D. 1984, Yale. - Ed.

** Student, Yale Law School. A.B. 1990, Princeton; M.Litt. 1993, Oxford. - Ed. This article is independent of, but builds upon, an earlier article. See Akhil Reed Amar, Fourth Amendment First Principles, 107 HaRv. L. Rev. 757 (1994).

For helpful comments on early drafts, we thank Bruce Ackerman, Vik Amar, Ian Ayres, Steven Bibas, Jon Blue, Paul Cassell, Mirjan Damaska, Steve Duke, George Fisher, Abe Goldstein, Nancy J. King, Stan Krauss, John Langbein, David Luban, Bill Stuntz, Bill Treanor, Eugene Volokh, Stephen Williams, and workshop members at the University of California at Davis, Chicago-Kent School of Law, George Washington University, the University of Pennsylvania Law School, Quinnipiac College School of Law, and Yale Law School.

1. U.S. CONST. amend. V. 
the slogan had stood for at least four different ideas. ${ }^{2}$ Today, things are no better: the clause continues to confound and confuse. $\mathrm{Be}-$ cause courts and commentators have been unable to deduce what the privilege is for, they have failed to define its scope in the most logical and sensible way. In this article we try our hand at solving the riddle and untying the Gordian knot. We propose both a rationale for, and a definition of the proper scope of, the Self-Incrimination Clause.

The Supreme Court's interpretation of the Fifth Amendment is currently in a jumbled transitional phase. The key question, though rarely recognized as such, is what sort of immunity the clause requires before a person may be made to tell all outside his own "criminal case," beyond the earshot of the petit jury. Over the years the answers have varied considerably. In its 1892 chestnut Counselman v. Hitchcock, 3 the Supreme Court required total ("transactional") immunity from prosecution whenever a person is compelled to testify against himself outside the courtroom. But in 1972, Kastigar v. United States ${ }^{4}$ in effect overruled Counselman and established a new, narrower rule of "use plus use-fruits immunity": a person forced to speak pretrial may be prosecuted, but neither the compelled statement nor any evidence it led to ("fruits") can be introduced in the criminal trial. Kastigar provided no persuasive basis for stopping where it did in fashioning its new rule, and the Court is slowly - if not always consciously - chipping away at the foundations of the new rule, emphasizing the difference between testimony and physical evidence. In this article we argue that the time is ripe to take a decisive step in the direction the Court has been leaning: the Court should move beyond the way station of Kastigar and declare that a person's (perhaps unreliable) compelled pretrial statements can never be introduced against him in a criminal case but that reliable fruits of such statements virtually always can be. Thus, the government should be allowed to require a suspect to answer relevant questions in a civilized pretrial hearing presided over by a judge or magistrate. Under penalty of contempt, a suspect must answer truthfully, but he will be entitled to "testimonial immunity": that is, the compelled words will never be introduced over the defendant's objection in a criminal trial - the defendant will never be an involuntary "witness" against himself

2. See John H. Langbein, The Historical Origins of the Privilege Against Self-Incrimination at Common Law, 92 MrCH. L. REv. 1047, 1084-85 (1994); infra section I.E.

3. 142 U.S. 547 (1892).

4. 406 U.S. 441 (1972). 
"in" a "criminal case" - but the fruits of these compelled pretrial words will generally be admissible.

This clean rule of testimonial immunity would openly vindicate the Court's recent emphasis on reliability as a preeminent criminal procedure value, but it has many other virtues as well. For starters, it has some important history on its side. Testimonial immunity, supported by English precedent, was the majority rule in America before Counselman and was explicitly endorsed by Congress at the time it adopted the Fourteenth Amendment, which reglossed the Bill of Rights and made its privileges and immunities applicable against the states. More importantly - as the long history of compelled self-incrimination is admittedly tangled - testimonial immunity makes the best sense of the words of the Fifth Amendment and kindred constitutional provisions, like those of the Sixth Amendment. Read our way, the words of the clause fit neatly together and tightly cohere with the rest of the Constitution. In short, our reading works, textually and functionally - no small thing in so muddy a field. Indeed, our proposal creates a rare win-win solution in criminal procedure: more guilty persons will be brought to book, while the plight of the truly innocent defendant will be improved.

Once we see the clear meaning of the rule against compelled self-incrimination - that self-incriminating words compelled from a defendant must be excluded from his criminal case - and the best reason underlying that rule - reliability - we can also see the independent roles that other rules must play, radiating from other clauses of the Constitution and motivated by other rationales. As we shall see, in both civil and criminal contexts, needlessly intrusive questioning, fishing expeditions, and offensive impositions upon a person's body raise obvious Fourth Amendment concerns; attempts to probe a citizen's mind for heresy or political incorrectness or a map of his inner life or conscience implicate the First Amendment; unregulated and lawless police behavior must be stamped out in the name of due process and the rule of law; and so on. By misreading - and often overreading - the scope and rationale of the SelfIncrimination Clause, courts and commentators have often obscured the proper role of other clauses, and so another happy side effect of our reading is that it yields a sensible division of labor among constitutional provisions.

The very breadth of the Self-Incrimination Clause, as currently construed, creates huge challenges, substantively and doctrinally, for this article. Substantively, we must note that an enormous amount of modern criminal law enforcement has been shaped by 
the Self-Incrimination Clause, as (mis)construed over the years. By narrowing government's ability to tap suspects as testimonial resources in civilized pretrial proceedings, the clause has driven some interrogation underground into less-than-civilized police station rooms and squad cars; has spurred on surprise searches, wiretaps, and other intrusions that fall outside the Fifth Amendment; has increased pressure to use "sting" operations and government informants, who often must be bribed in unappealing ways; and has ramified in countless other directions. A different reading of the Self-Incrimination Clause would likewise ripple out far and wide, and a single article cannot trace all these likely ripples with precision. On the other hand, the vast substantive significance of the Self-Incrimination Clause only deepens the puzzle of current doctrine and scholarship, which cannot persuasively explain what the clause means and why.

Doctrinally, the vastness of the Self-Incrimination Clause, sprawling across the U.S. Reports into a great many doctrinal corners and crevices, makes exposition difficult. It is hard to get one's hands on the beast, and there is no self-evidently superior way of organizing the multiheaded case law for exposition and analysis. In this article we have chosen the technique - call it a gimmick, if you like - of organizing our account around key words of the clause itself. 5 Each word can be used as a window onto a different cluster of doctrinal difficulties. Although these clusters might at first seem unconnected, by the end of this article we hope to pull them all together - to show how each cluster of current problems can be solved by the same elegant rereading of the Self-Incrimination Clause.

In Part I of this article, we examine the global puzzle of the SelfIncrimination Clause and the local confusion or perversion lurking behind virtually every key word and phrase in the clause as now construed. In Part II we elaborate our reading of the clause and show how it clears up the local problems and solves the overall puzzle.

\section{The Puzzle}

Under current interpretations, courts cripple innocent defendants while the guilty wrap themselves in the clause and walk free. Modern understandings of the clause deviate far from its early

5. For a similar organizational strategy, see Bruce A. Ackerman, Beyond Carolene Products, 98 HaRv. L. Rev. 713 (1985). 
American implementation, from plain meaning, and from common sense. The catalogue of interpretive difficulties is long: the privilege protects the wrong "person" - the guilty witness rather than the innocent defendant; courts struggle with impractical definitions of "compulsion"; what is excluded from "any criminal case" by grants of immunity has fluctuated widely over the years; and reliable physical fruit, such as a bloody knife or a dead body, is now excluded because it is "witnessing" against oneself, while other reliable physical evidence (the defendant's own blood, for example) is allowed because it is not testimonial. In short, virtually every word and phrase - person, compelled, in any criminal case, and witness - sits atop considerable confusion or perversion because courts do not yet understand how the words fit together, or what big idea(s) might underlie the clause.

\section{A. "Person"?}

Perhaps the most striking flaw in current application of the privilege is that in some important cases defendants are not helped but harmed. And worse: the privilege seems perversely designed to aid the guilty defendant while punishing the innocent one. Indeed, an overbroad reading of the privilege ends up undercutting the most basic of all criminal procedure rights - the right of an innocent defendant to mount a truthful defense.

Begin with the following question: Does the Self-Incrimination Clause prevent a "person" in a criminal case from being compelled to testify against himself even when that person is not on trial but only a witness? Today the answer is yes. As a result, the Fifth Amendment prevents an innocent defendant from compelling selfincriminating testimony from a guilty witness. But this invocation of the Fifth Amendment by the witness denies the accused her explicit Sixth Amendment right "to have compulsory process for obtaining witnesses in [her] favor." 6 The Fifth and Sixth Amendments seem to be at war with one another, and the Fifth Amendment rights of a witness apparently trump the Sixth Amendment rights of the defendant, even though the defendant is of course the "person" whose criminal case it is. ${ }^{7}$

6. U.S. Const. amend. VI (emphasis added).

7. The quandary of an innocent defendant who wishes to show that someone else committed the crime is highlighted by Professor Peter Tague. See Peter W. Tague, The Fifth Amendment: If an Aid to the Guilty Defendant, an Impediment to the Innocent One, 78 GEO. L.J. 1 (1989). 
Let's consider a simple situation - a single defendant truthfully claiming that she is innocent and that another specific person committed the crime - and trace the sequence of events that would most likely follow in a criminal trial. ${ }^{8}$ Defendant subpoenas the guilty party to testify at her trial, in accordance with her explicit Sixth Amendment right to "comp[el]" the production of "witnesses in [her] favor." The guilty witness notifies defense counsel before trial that he will refuse to testify, invoking his Fifth Amendment privilege not to be "compelled" to be a "witness" against himself. After defense counsel informs the judge of the witness's intent, the judge conducts a hearing to determine whether the witness may assert the privilege. At the hearing, the witness refuses to answer questions. This refusal, combined with other evidence the defense has discovered suggesting the witness's guilt, convinces the judge that the witness might incriminate himself were he to testify truthfully. The court therefore holds that the witness may assert the privilege.

Faced with the witness's silence, the defendant begs the prosecution to grant the witness immunity to compel him to testify. ${ }^{9}$ Note the imbalance of power here. While the prosecution can freely grant immunity and compel witnesses to testify, the defense has no such power. At a minimum, one might have thought the defendant's explicit Sixth Amendment right of compulsory process should put her on a level playing field with the prosecution; if the prosecutor is empowered to subpoena a reliable witness, the defendant should be so empowered. ${ }^{10}$ Prima facie, it might seem that the

8. This account is drawn from Peter Tague. See id. at 1-3.

9. As will be explained in more detail infra in section I.C, the type of immunity now required is "use plus use-fruits" immunity, which prevents the prosecution from using either the words of the testimony or any evidence (fruits) found as a result of the testimony. See Kastigar v. United States, 406 U.S. 441, 453 (1972).

10. See Webb v. Texas, 409 U.S. 95, 96, 98 (1972); Washington v. Texas, 388 U.S. 14, 22 (1967); 388 U.S. at 24-25 (Harlan, J., concurring). New Jersey's state constitutional precursor of the federal compulsory process clause explicitly gave defendants "the same privileges of witnesses . . . as their prosecutors are or shall be entitled to." N.J. CoNST. art. XVI (1776) (emphasis added). This provision traces back to William Penn's 1701 Pennsylvania Charter of Privileges: "THAT all criminals shall have the same Privileges of Witnesses . . . as their Prosecutors." PA. Charter, art. V (1701) (emphasis added). Similarly, Sir William Blackstone's widely influential treatise defined the compulsory process principle as giving the defendant "the same compulsive process to bring in his witnesses for him, as was usual to compel their appearance against him." 4 WILLIAM BLACKSTONE, COMMENTARIES "352 (emphasis altered). Blackstone's formulation in tum built on the landmark Treason Act of 1696, 7 Will. 3, ch. 3, § 7 (Eng.) (emphasis added). See infra note 11. This Act gave defendants "the like process ... to compel their witnesses ... as is usually granted to compel witnesses to appear against them." 7 Will. 3, ch. 3, \& 7 (1696) (Eng.) (emphasis added). James Madison's particular "compulsory process" phraseology in the Sixth Amendment appears to borrow directly from Blackstone. See Peter Westen, The Compulsory Process Clause, $73 \mathrm{Mich}$. L. REv. 71, 97-98 \& n.114 (1974). On compulsory process parity more generally, see $i d$. at 78 , 
same should hold true for the immunity-granting power. But instead, the defendant is forced to rely on the good graces of the prosecutor. ${ }^{11}$ The prosecution, however, has little incentive to grant immunity in this situation. The prosecutor reasons as follows: ${ }^{12}$ If the witness confesses falsely and the defendant is acquitted, a guilty party gets off; ${ }^{13}$ and if the witness confesses truthfully, the immunity itself will make it hard to ever prosecute and convict him - and so, here too, a guilty party gets off. ${ }^{14}$ The prosecutor therefore refuses the defendant's request that the government grant the witness immunity. Frustrated, the defendant asks that the court require the prosecution to grant immunity. The vast majority of courts would reject such a request, ${ }^{15}$ and the reasons here are obvious. Immunity can create a major stumbling block to prosecuting the witness on

$95,116,128,140$ n. 331, 147-48, 158-59, 168, and 177-82. General privileges - spousal, priestpenitent, and so on - which put limits on the government as well as the defendant, raise different issues and thus lie beyond the scope of our discussion.

11. Our legal forebears attempted to correct this sort of imbalance as early as the $1690 \mathrm{~s}$, when Parliament enacted the Treason Act. This landmark Act granted the defendant in treason cases many of the same powers the prosecution had, including the right to legal representation and compulsory process to obtain witnesses. See Langbein, supra note 2, at 1056, 106768. In the midst of this seventeenth-century striving for parity between prosecution and defense, grants of immunity were not included because the privilege against self-incrimination did not exist. See id. at 1074-84.

12. Although we have stipulated that the defendant is in fact innocent, the prosecutor, of course, may not know or believe this.

13. A perjury prosecution against the lying witness is of course possible, but perjury can be hard to prove beyond a reasonable doubt, and a perjury prosecution may be less important than the original case from the prosecutor's perspective.

14. Tague thinks that the prosecution "has no substantive reason" to refuse to grant immunity to the witness in single-culprit cases. See Tague, supra note 7, at 37,53. The reasons seem obvious enough.

15. One of the only exceptions appears to be the Third Circuit, which has held that a court can order a prosecutor to grant immunity and also that a court can grant the immunity itself in certain situations. See United States v. Herman, 589 F.2d 1191, 1204 (3d Cir. 1978) (holding that a court can order a prosecutor to grant immunity to a defense witness when the prosecutor has withheld the grant for the purpose "of distorting the judicial fact finding process"), cert. denied, 441 U.S. 913 (1979); Government of the Virgin Islands v. Smith, 615 F.2d 964, 969 (3d Cir. 1980) (holding that a court can grant immunity itself if a defendant is otherwise "prevented from presenting exculpatory evidence which is crucial to his case"). Most courts, however, have refused to grant immunity even if the testimony is crucial to a defendant's case. See, e.g., United States v. Heldt, 668 F.2d 1238, 1282-83 (D.C. Cir. 1981) (holding that a trial court should not grant immunity to defense witnesses who are actual or potential targets of prosecution).

For academic commentary on the subject, see Westen, supra note 10, at 166-70 (arguing that courts have the constitutional ability to grant immunity or to force prosecutors to grant immunity) and Peter Westen, Incredible Dilemmas: Conditioning One Constitutional Right On the Forfeiture of Another, 66 lowa L. REv. 741, $762-75$ (1981) [hereinafter Westen, Incredible Dilemmas] (providing more elaboration of this view). See also James F. Flanaghan, Compelled Immunity for Defense Witnesses: Hidden Costs and Questions, 56 NOTRE DAME L. REv. 447, 461-63 (1981) (arguing against judicial grants of immunity for defense witnesses in multiculprit crimes on the practical grounds that in the eventual prosecution of the witness, the prosecutor would have difficulty proving that she gathered evidence without the aid of the witness's testimony). 
anything related to his testimony. (The government will have to prove that nothing in its case is in any way derived from the testimony, and as we shall see in more detail below, this can be a very hard thing to prove.) Indeed, in organized crime settings the first defendant will be tempted to give all his partners an immunity bath.

To add insult to injury, the jury would not even hear, from the witness or anyone else, that the witness claimed the privilege. At trial, the defendant could introduce evidence against the witness but could not force him to invoke the privilege in front of the jury. ${ }^{16}$ At most the defendant could request an instruction that the jury must not draw any inference against either side from the witness's failure to appear. ${ }^{17}$ On the other hand, merely forcing the witness to assert the privilege before the jury might make collusion between defendant and witness easier. ${ }^{18}$ In general, the jury would be left with considerable uncertainty about why the witness is asserting the privilege; jurors could learn far more from actual testimony than from a mere assertion of the privilege.

Of course, even if immunity were conferred, the guilty witness might take the stand and lie, denying all involvement. But the witness need not break down and deliver a full-blown confession Perry Mason style to make all the difference for an innocent defendant. A lying witness may well sound unconvincing or trip himself up with inconsistent testimony; he will also be subject to impeachment via cross-examination and defense introduction of other evidence and witnesses. The jury would then be perfectly poised to assess witness credibility and to resolve factual disputes. This, of course, is what we pay jurors to do.

So in the end we are left with the following puzzle. Precisely because Fifth Amendment immunity is so strong, innocent defendants are crippled in their effort to mount a Sixth Amendment defense. Might the solution be to rethink Fifth Amendment immunity? ${ }^{19}$

16. Tague notes that every U.S. court that has considered the issue has so held. See Tague, supra note 7, at 5 . For the reasons behind this view, see $i d$. at 13-52.

17. Id. at 2.

18. But see id. at $40-43$ (discounting this concem).

19. Cf. Amar, supra note **, at 783 ("[U]njustified expansions of constitutional rights often lead to dangerous and unjustified contractions elsewhere."). For a good illustration of this principle in the Fifth Amendment context, see Allen v. Illinois, 478 U.S. 364, 369-75 (1986) (holding that proceedings under one state's Sexually Dangerous Persons Act were not "criminal" despite the potential for moral stigma and incarceration in a maximum security institution). The Allen Court's characterization of the case as "noncriminal" eliminated the need to apply self-incrimination principles, which the Court thought undermined the reliability of fact-finding. 478 U.S. at 375. As we shall see, however, the Self-Incrimination Clause, rightly understood, is not at war with reliability. See infra Part II. Had the Allen Court 


\section{B. "Compelled"?}

The Fifth Amendment does not prohibit all self-incrimination but only compelled self-incrimination. How should we go about construing the word compelled? Some leading Framers thought of the Self-Incrimination Clause as a protection against torture, which might often lead to unreliable confessions. ${ }^{20}$ Our main concerns today should still be protecting against third-degree tactics and assuring reliability in evidence. Instead, at times the Justices of the Supreme Court have become engrossed by relatively trivial forms of compulsion; at other times they have zigged and zagged erratically; and at still other times they have turned a blind eye to dangerous compulsion threatening our core concerns.

\section{In-Court Compulsion}

At times, compulsion seems to be defined as making someone who "takes the Fifth" worse off in any way than one who sings without reservation. Under this definition, the government may not draw any adverse inference if a person insists on standing mute in the face of an accusation of criminal wrongdoing. In its controversial 1965 opinion in Griffin v. California, ${ }^{21}$ the Supreme Court es-

properly construed the clause, it might have been more inclined to admit that the case before it was indeed criminal. Instead, a "broad" reading of the Self-Incrimination Clause ended up eliminating the defendant's explicit constitutional right to other "criminal" procedure safeguards outlined in the Sixth Amendment.

20. During the debates over ratification of the Federal Constitution, several participants expressed fears that the Constitution failed to provide common law protection against torture to extract confessions. In Virginia, Patrick Henry wamed that

Congress may introduce the practice of the civil law, in preference to that of the common law. They may introduce the practice of France, Spain, and Germany - of torturing, to extort a confession of the crime. ... [T] necessity of strengthening the arm of government, that they must have a criminal equity, and extort confession by torture, in order to punish with still more relentless severity.

3 The Debates in the Several State Conventions on the Adoption of the Federal Constirution 447-48 (Jonathan Elliot ed., 1886). George Nicholas retorted that Henry's argument about torture applied equally to the Virginia Constitution. See 3 id. at 450-51. At this point, George Mason, the drafter of Virginia's Bill of Rights, jumped into the fray and argued that his state's Bill of Rights did prohibit torture: "[O]ne clause expressly provided that no man can give evidence against himself; and ... [Nicholas] must know that, in those countries where torture is used, evidence was extorted from the criminal himself." $3 \mathrm{id}$. at 452; see also 2 id. at 111 (recording remarks by Abraham Holmes in the Massachusetts debates linking torture and the Inquisition with the federal government's ability to compel a man to furnish evidence against himself). Leonard Levy has noted that references to the privilege are scarce in the literature and debates surrounding the ratification of the Constitution and the Bill of Rights. See LeONARD W. LEVY, ORIgINS OF THE FifTH AMENDMENT: THE RIght Against SELF-INCRIMINATION 430 (1968). The Framers occasionally acknowledged that the privilege served as a ban on torture, but "nothing can be found of a theoretical nature expressing [an additional] rationale or underlying policy for the right in question or its reach." Id.

21. 380 U.S. 609 (1965). 
tablished this as the test of in-court compulsion. A defendant had an absolute right not to take the stand, and no adverse inference of guilt could be drawn from the exercise of this trial right. Any inference, said the Court, was tantamount to criminal punishment of trial silence itself, a core violation of the clause's command. ${ }^{22}$

But this begs the question: if the adverse inference was indeed probabilistically sound, was it truly punishing silence, or the (more probable) guilt signalled by the silence? On its facts, however, the in-court rule may well make sense. As we shall see in more detail later, many innocent defendants may decline to take the stand for reasons that have little to do with their guilt in the case at hand,23 and so an adverse inference might be statistically unsound and unreliable ${ }^{24}$ and therefore may punish silence itself, rather than underlying guilt on the predicate offense. Under the reliability theory we shall outline below, Griffin can stand.

The Supreme Court, however, has failed to make clear how Griffin should apply when a criminal court acts in the sentencing phase rather than the guilt-determination stage of a criminal case and seeks to draw inferences from a defendant's earlier (preverdict) silence. Even if adverse inferences are unreliable to prove guilt, perhaps they may be reliably used in the sentencing process, after guilt has already been reliably established. The Federal Sentencing Guidelines, for example, authorize a lower sentence for a defendant who "accept[s] . . . responsibility for his offense" as evidenced by, among other things, "truthfully admitting the conduct comprising the offense(s) of conviction" or "assist[ing] authorities in the investigation or prosecution of his own misconduct by taking

22. See 380 U.S. at $614-15$.

23. The innocent defendant may want to avoid taking the stand because he is likely to perform badly, being inarticulate and concerned that an experienced prosecutor, skilled in the artificial rules governing courtrooms, will be able to trip him up. The jury, our innocent defendant might also fear, will likely overreact to any real or perceived slip up on his part on the stand. In addition, he may be worried that his prior convictions will come in to impeach his credibility, wrongly inducing the jury to think that he must also be guilty in the case at hand. The latter problem may be cured by a provision, such as MONT. R. Evid. 609, that states that prior convictions are not available to attack credibility. The former problem, however, cannot be cured so easily.

24. See infra section II.E; see also Stephen J. Schulhofer, Some Kind Words for the Privilege Against Self-Incrimination, 26 VAL. U. L. Rev. 311, 330-35 (1991) (defending Griffin on similar grounds). So too, even if silence were mildly probative, a typical jury might draw far too large an adverse inference, and this also (by hypothesis) would be statistically unsound. In this situation, Griffin's rule overprotects - by disallowing instructions to the jury that an inference can be made - but a more carefully tailored instruction to "infer, but not too much" might be unworkable. 
one or both of the steps set forth in subsection (b)."25 One of the steps in subsection (b) involves the "timely provision of complete information to the government concerning his own involvement in the offense." 26 The common-sense logic and morality of these guidelines are easy to see: those who repent and admit their misdeeds in open court before conviction may need less rehabilitation and deserve less punishment in the sentencing process.

But can this everyday morality be squared with the logic of the Self-Incrimination Clause and Griffin? Are courts in effect punishing silence - and in a criminal case, no less? On the other hand, if the Sentencing Guidelines can be upheld, and Griffin limited, on the basis of a guilt-determination/sentencing distinction, what would such a distinction imply about the meaning and purpose of the Self-Incrimination Clause? (Wouldn't it, for example, suggest that the key to the clause is reliability?) Finally, if a defendant appeals, wins, and is retried, can he exclude, in the guilt-determination stage of his second trial, any earlier statements on the grounds that they were compelled by the "silence penalty" imposed by the Sentencing Guidelines? Lower courts need to know which silence penalties are valid under the Self-Incrimination Clause, and the Supreme Court has not yet announced a theory of the clause that can inform them. ${ }^{27}$

25. U.S. Sentencing Commn., Federal Sentencing Guidelines Manual § 3.E1.1 (1993 ed.).

26. Id.

27. The Supreme Court denied certiorari in a recent case raising the issue of whether the sentencing reduction can be conditioned on defendant's admitting to uncharged conduct. Kinder v. United States, 112 S. Ct. 2290 (1992). The defendant agreed to a plea bargain but then was denied the sentencing reduction when he refused to admit to conduct to which he had not pled guilty. As Justice White pointed out in his dissent to the denial of certiorari, there is a circuit split on this question. See 112 S. Ct. at 2293 (White, J., dissenting).

In contrast, courts seem to agree that the sentencing reduction can be conditioned on the defendant's admitting to conduct for which he has been convicted. See, for example, United States v. Henry, 883 F.2d 1010 (11th Cir. 1989):

"[T]he guideline recognizes societal interest in ... the increased potential for rehabilita-

tion among those who feel and show true remorse for their anti-social conduct."

....

... To hold the acceptance of responsibility provision unconstitutional would be to say that defendants who express genuine remorse for their actions can never be rewarded at sentencing. This the Constitution does not require.

883 F.2d at 1011-12 (quoting United States v. Belgard, 694 F. Supp. 1488, 1497-98 (D. Or. 1988)). But if we follow the seeming logic of Griffin's "no worse off" test, such a condition would also violate the privilege, and no court has explained how Griffin is to be distinguished away.

It might be claimed that intervening cases upholding plea bargaining have eroded Griffin: a defendant who pleads not guilty may be penalized more severely than - made worse off compared to - a defendant who pleads guilty. $C$ f. Brady v. United States, 397 U.S. 742, 74954 (1970). Formally, however, pleading and witnessing are not the same thing; a plea bargain may benefit a defendant whether or not he would have taken the stand as a witness at trial. 


\section{Out-of-Court Compulsion: Government Employment}

In a series of cases involving public employees, the Supreme Court tried to stretch the in-court Griffin rule to govern conduct well outside the courtroom - indeed, outside the criminal justice system. ${ }^{28}$ The cases held that the threat of removal from government employment was compulsion for the purposes of the Fifth Amendment, incorporated through the Fourteenth; they concerned individuals such as allegedly corrupt police officers and dishonest state contractors who successfully claimed a right to keep their government jobs while refusing to respond to allegations of wrongdoing. ${ }^{29}$

But outside the courtroom, the "no worse off" test seems extravagant and unworkable: the logical consequences are absurd. Couldn't President Reagan have refused to appoint Oliver North to be Secretary of State - or fired him from his subcabinet White House office, for that matter - on the simple ground that North's invocation of the Fifth Amendment raised sufficient doubt about his worthiness to serve in a position of high honor and power? Merely focusing preliminary investigation on someone who takes the Fifth also makes that person worse off, and yet - so far - the courts have allowed the government to do just that.30 Even if within a courtroom a jury should be barred from drawing adverse inferences from trial silence, the real world outside the courtroom cannot be regulated by so nice a test of compulsion; people in everyday life must draw reasonable inferences. 31 A responsible private employer may draw sensible inferences from silence and fire the bank clerk who refuses to respond to accusations of pilfering. ${ }^{32}$

Thus, the plea-bargaining cases may not resolve the arguably distinct witnessing issues raised by the "silence penalty" in sentencing.

28. As we shall see in more detail, see infra section I.C, the Fifth Amendment protects against compelling statements outside a "criminal case" if those statements are later usable inside a criminal case - at a criminal trial.

29. See Lefkowitz v. Turley, 414 U.S. 70 (1973) (holding that a state could not cancel existing contracts of and deny future contracts to a contractor who refused to testify without immunity concerning state contracts); Gardner v. Broderick, 392 U.S. 273 (1968) (holding that a state could not discharge a police officer who refused to testify without immunity before a grand jury about the performance of his official duties); Uniformed Sanitation Men Assn. v. Commissioner of Sanitation, 392 U.S. 280 (1968) (announcing a similar holding in a companion case concerning sanitation workers).

30. See Stephen A. Saltzburo \& Daniel J. Capra, American Criminal Procedure 456 (4th ed. 1992).

31. Some of the reasons that an innocent person might stand mute in a technical legal proceeding governed by artificial and unfamiliar rules would not apply to informal accusation in some noncourt settings. See infra section II.E.

32. Even Dean Griswold acknowledged the appropriateness of a private employer's firing someone who refused to answer questions about his job. See ERWIN N. GRIswOLD, THE 
Yet the "no worse off" test forces the government to act as an irresponsible employer - ignoring common sense - or else confer immunity and possibly lose valuable evidence in its capacity as sovereign enforcer of criminal law. (Once again, it loses this evidence unless it can conclusively prove at trial that the evidence was in no way connected to the earlier "compelled" words. ${ }^{33}$ ) Is it possible that, here too, this immunity rule is too broad?

So it seems that the "no worse off/no adverse inference" test simply will not work as a global rule of impermissible compulsion outside the courtroom. Indeed, in the 1976 case of Baxter $v$. Palmigiano, 34 the Court seemed to reject the "no worse off" test even for prison disciplinary hearings. The Court allowed adverse inferences to be drawn in a disciplinary hearing against a prisoner who refused to respond to questions unless he was immunized. ${ }^{35}$ Once we reject the "no worse off" test, however, we flounder in a sea of murky rules. How much pressure to talk is too much? And how can we even begin to answer this question without a theory of why pressure is bad?

\section{Out-of-Court Compulsion: Required Records}

A prime example of the confusion that results when the Court strays from the "no worse off" test is the required records doctrine. The Court has been unable to develop a consistent rule for the use in criminal proceedings of records that the government requires citizens to keep for administrative purposes. ${ }^{36}$ The cases essentially set up an open-ended test that allows the Court to swing from ad-

Fifth AMEndment Today 57-58 (1955); see also Adamson v. California, 332 U.S. 46, 60 (1947) (Frankfurter, J., concurring) ("Sensible and just-minded men, in important affairs of - life, deem it significant that a man remains silent when confronted with serious and responsible evidence against himself which it is within his power to contradict.").

33. In essence, Fifth Amendment immunity raises "causation gap" issues analogous to those raised by the Fourth Amendment exclusionary rule. For a discussion of this causation gap, see Amar, supra note **, at 793-95.

34. 425 U.S. 308 (1976).

35. 425 U.S. at 318 ("[Palmigiano's] silence was given no more evidentiary value than was warranted by the facts surrounding his case."). The Court felt that other constitutional protections, such as the Sixth Amendment right to counsel, were not required in the prison disciplinary context. See 425 U.S. at 315 . In civil cases, we routinely allow adverse inferences to be drawn when a witness "takes the Fifth." But, it might be argued, in civil cases it is generally not the government that benefits from the inference; the beneficiary is the opposing private party, and the government merely adjudicates. By that logic, adverse inferences from silence in civil cases could be drawn in favor of private parties, but not in favor of the government when it is a party in a civil suit. Like the cases involving the government in its capacity as an employer, this puts the government in an unjustifiably weaker position than comparable private actors.

36. Again, a Fifth Amendment violation occurs at the point when compelled testimony is introduced in a criminal case. See supra note 28 ; infra note 63 . 
mitting the records to excluding both the records and their fruits without any principled basis.

The 1948 case that spawned the doctrine, Shapiro $v$. United States, ${ }^{37}$ arose out of emergency wartime regulations and seemed to place few limits on the required records exception to the Fifth Amendment. Shapiro, a produce wholesaler during World War II, was required to keep price, sale, and delivery records and to make them available for inspection under the Emergency Price Control Act. ${ }^{38}$ Shapiro complied with a subpoena to produce his records but claimed his constitutional privilege. The government, however, proceeded to prosecute him for illegal tie-in sales, using the records and their fruits. A closely divided Supreme Court held that the Self-Incrimination Clause did not apply to the subpoenaed documents; because Shapiro was required by law to keep the records, they were unprotected public documents rather than protected private papers. ${ }^{39}$ In his dissent, Justice Frankfurter pointed out some of the deep fiaws in the Court's reasoning:

Subtle question-begging is nevertheless question-begging. Thus: records required to be kept by law are public records; public records are non-privileged; required records are non-privileged. If records merely because required to be kept by law ipso facto become public records [and therefore fall outside the scope of the privilege], we are indeed living in glass houses. ${ }^{40}$

We must keep in mind that the rule of immunity at that time was laid down by Counselman ${ }^{41}$ - complete immunity from prosecution for the crime. This no doubt encouraged the Shapiro Court's failure to define any limits to the "public" records Congress might require, except those limits imposed by its enumerated powers. Government had legitimate regulatory need of the information, and the Court was unwilling to force the government to vindicate its legitimate regulatory needs only by abdicating - via sweeping immunity - its role as criminal law enforcer. As in the employment

37. 335 U.S. 1 (1948).

38. Emergency Price Control Act of 1942, ch. 26, 56 Stat. 23 (repealed 1966).

39. 335 U.S. at 32-33. Chief Justice Vinson, possibly influenced by the wartime, emergency nature of the regulations, wrote for the Court:

[N]o serious misgiving that [the bounds imposed by the Fifth Amendment] have been overstepped would appear to be evoked when there is a sufficient relation between the activity sought to be regulated and the public concem so that the Government can constitutionally regulate or forbid the basic activity concerned, and can constitutionally require the keeping of particular records, subject to inspection by the Administrator. 335 U.S. at 32. He then noted that Congress unquestionably had the constitutional power to control commodity prices as a wartime emergency measure. 335 U.S. at 32.

40. 335 U.S. at 51 (Frankfurter, J., dissenting).

41. Counselman v. Hitchcock, 142 U.S. 547 (1892). 
context, is it possible that the real problem here is that immunity has been defined too broadly?

In later cases, the Court has struggled to establish limits to the required records exception, but the limits have remained fuzzy. In 1968, the Court decided three required documents cases on the same day, all authored by Justice Harlan and all reversing convictions because of violations of the Fifth Amendment. The first, Marchetti v. United States, ${ }^{42}$ controlled the rest. ${ }^{43}$ Marchetti had been convicted of willful failure to pay the occupational tax associated with gambling and of willful failure to register as a wagerer. Justice Harlan cobbled together bits from earlier cases into a threepronged pseudo-test to distinguish Shapiro, but the test failed to undo the confusion produced by earlier cases. Under the test, courts were to inquire, first, whether the defendant was obliged to keep records "of the same kind as he has customarily kept;" 44 second, whether there were "public aspects" involved in the records required; 45 and third, whether a records requirement was "imposed in 'an essentially non-criminal and regulatory area of inquiry'" or was instead "directed to a 'selective group inherently suspect of criminal activities." "46 The prongs were intriguing but not well defined or well justified.

Although the Court found Fifth Amendment violations in the 1968 Marchetti trilogy, in 1971 the Court lurched the other way and upheld the constitutionality of California's hit-and-run statute in California v. Byers. ${ }^{47}$ Byers had been convicted of failing to stop at the scene of an accident and failing to leave his name and address. The California Supreme Court required a use restriction on the information, ${ }^{48}$ but the U.S. Supreme Court held that because the statute did not violate the Fifth Amendment, no use restriction was required. 49 Chief Justice Burger, writing for a plurality, struggled to find a rationale for holding that the privilege did not apply. $\mathrm{He}$ invoked some elements of the Marchetti test, but the opinion elsewhere veered away from the test. At one point, the Chief Justice

42. 390 U.S. 39 (1968).

43. The other two cases were Grosso v. United States, 390 U.S. 62 (1968) (reversing a conviction for failure to pay an excise tax on wagers) and Haynes v. United States, 390 U.S. 85 (1968) (reversing a conviction for possession of an unregistered firearm).

44. 390 U.S. at 57.

45. 390 U.S. at 57.

46. 390 U.S. at 57.

47. 402 U.S. 424 (1971).

48. See Byers v. Justice Court, 458 P.2d 465, 477 (1969).

49. 402 U.S. at 427 n.3. 
seemed to announce a new principle in self-incrimination cases, and one completely lacking in textual support: questions about whether the privilege should apply "must be resolved in terms of balancing the public need on the one hand, and the individual claim to constitutional protections on the other."50

The Court further stretched the required records doctrine in the 1990 Bouknight case, ${ }^{51}$ in which Justice O'Connor relied heavily on the exception to prevent the privilege from applying in a disturbing case of child abuse. In Bouknight, a mother suspected of child abuse was given custody of her injured child with extensive conditions imposed by a protective order. The mother violated those conditions, and a court ordered her to produce the child in order to verify that the child was alive and well. When she refused, the court held her in contempt and rejected her contention that the Fifth Amendment protected her from having to produce him. The Supreme Court invoked Shapiro, Marchetti, and Byers, explaining that the requirement to produce the child involved a "broadly directed, noncriminal regulatory regime" 52 - that the state was attempting to help "a child in need of assistance" 53 and was not solely concerned with criminal law enforcement. ${ }^{54}$

The inconsistency of these cases is striking and revealing. The Court hems and haws and then often holds that the privilege does not apply at all: the government often needs information for nonpenal purposes and should not be forced to let criminals go free to get it, the Court intuits. The Court is understandably reluctant to apply the privilege in a heinous crime such as child abuse; granting use plus use-fruits immunity would make it difficult, and in some cases (including the hit-and-run) almost impossible, to prosecute. But that is what Kastigar ${ }^{55}$ currently demands. Unable to live with that result, the Court zigs, zags, and balances, ad hoc. But the language of the Self-Incrimination Clause does not balance: it states a bright-line rule. Is it possible that if immunity were narrower than

50. 402 U.S. at 427 (emphasis added).

51. Baltimore City Dept. of Social Servs. v. Bouknight, 493 U.S. 549 (1990).

52. 493 U.S. at 559.

53. 493 U.S. at 559.

54. The Court, however, did not categorically state that Bouknight would not be allowed any immunity: "We are not called upon to define the precise limitations that may exist upon the State's ability to use the testimonial aspects of Bouknight's act of production in subsequent criminal proceedings." 493 U.S. at 561 . As we shall see below, this caveat in effect sidesteps the real issue in the case and under the clause generally: the scope of the immunity that must be given in a criminal case.

55. Kastigar v. United States, 406 U.S. 441 (1972). 
Kastigar indicates, judges could indeed live with the logic of the bright-line rule?

\section{Out-of-Court Compulsion: Police Interrogation}

When it comes to genuine out-of-court coercion, courts at times turn a blind eye. While Miranda ${ }^{56}$ purported to establish propriety in police-station interrogation, our system in fact can still be quite ugly. Despite Miranda's promise to open up the black box of the police station, it did not require that lawyers, magistrates, or even tape or video recorders be present in interrogation rooms. In the absence of these monitors, detectives and police have often engaged in ingenious, but troubling, forms of interrogation.

In some instances, courts actually succeed in chilling clever tactics, with a resulting loss of information for the prosecution, but in other cases the judicial decisions have created a divergence between theory and practice. A good recent description of this divergence - and of suspect interrogation in general - is found in David Simon's 1991 book based on unlimited access to the Baltimore homicide detective unit over the course of a year. ${ }^{57}$ Some of the techniques used by detectives could aptly be described as physically intimidating, teetering on the brink of violence. Simon describes detectives doing everything from slamming doors and kicking chairs, swearing, and interrogating late at night to lying about the evidence against the suspect and about the detective's ability and willingness to get the suspect a lower sentence. ${ }^{58} \mathrm{Sev}-$ eral of the techniques are ingenious, most notably "polygraph by photocopier."59 But most people would find them uncivilized, at

56. Miranda v. Arizona, 384 U.S. 436 (1966).

57. See David Simon, Homicide: A Year on the Kirimng Streets 199-220 (1991). Simon is a reporter for the Baltimore Sun who spent four years on the police beat before his research leading to Homicide. Simon concludes, "[I]f the ... intent of the Miranda decision was, in fact, an attempt to 'dispel the compelling atmosphere' of an interrogation, then it failed miserably." Id. at 199.

58. Id. at 204-20.

59. Recently, several experienced homicide detectives in Detroit were publicly criticized and disciplined by their superiors for using the office copy machine in purported lie detector tests. The process worked as follows:

[T] he detectives, when confronted with a statement of dubious veracity, would some-

times adjoum to the Xerox room and load three sheets of paper into the feeder.

"Truth," said the first.

"Truth," said the second.

"Lie," said the third.

Then the suspect would be led into the room and told to put his hand against the side of the machine. The detectives would ask the man's name, listen to the answer, then hit the copy button.

Truth.

And where do you live? 
best. We do not tolerate such behavior in civil litigation. 60 Rather, we use depositions - with court reporters, lawyers, and judicial oversight.

Here, too, we are left with a puzzle. Perhaps the police are tempted to subvert formal rules because the rules make no sense. A suspect, even if ultimately innocent, is often someone close to the action, someone who can tell the government what really happened so that the case can be solved. ${ }^{61}$ But formal doctrine prevents the government from using the suspect as an involuntary testimonial resource unless the government confers a sweeping immunity that will often preclude prosecution. By effectively preventing formal, civilized depositions - by creating an overly strong Fifth Amendment immunity - perhaps we are driving interrogation underground, in ways that make some citizens more vulnerable and the weakest most vulnerable of all.62 So could it be that here, again, the most sensible solution would be to rethink immunity?

\section{C. "In Any Criminal Case"?}

The government compels persons to be witnesses to their own criminal conduct all the time - in strict conformity with the Constitution, we are told. All that is required is immunity of a certain sort, enforced by rules of exclusion "in any criminal case" against the witness. ${ }^{63}$ But immunity of what sort? This is the hidden key to

\footnotetext{
Truth again.

And did you or did you not kill Tater, shooting him down like a dog in the 1200 block of North Durham Street?

Lie. Well, well ....

Id. Occasionally, a confession would result.

60. See William J. Stuntz, Lawyers, Deception, and Evidence Gathering, 79 VA. L. Rev. 1903,1905 (1993) ("Deception and advantage taking are . . . at the core of criminal investigation, even though legal ethics doctrine largely banishes them from the evidence-gathering process in civil cases."). Of course, we are not proposing to abolish all governmental "deception" - sting operations, undercover agents, and the like. We largely agree with Professor Stuntz that criminal law enforcement should not be constrained by all the rules applicable to civil litigation. But we will argue that certain more "civilized" techniques, like depositions, should be available to criminal law enforcement officers. See infra Part II.
}

61. Langbein, supra note 2, at 1055.

62. Cf. Paul G. Kauper, Judicial Examination of the Accused - A Remedy for the Third Degree, 30 Mrch. L. REv. 1224 (1932); Yale Kamisar, Kauper's "Judicial Examination of the Accused" Forty Years Later - Some Comments on a Remarkable Article, 73 Mich. L. REV. 15 (1974).

63. Some have argued that the Fifth Amendment cannot mean what it says - that, contrary to its words, it must apply to compulsion outside a criminal case. Surely (the argument goes), we cannot allow a prosecutor to recess a criminal trial; walk across the street and compel - upon pain of contempt - a defendant to answer questions; and then walk back across the street, reconvene the trial, and introduce as evidence both a transcript and a videotape of the compelled statement. What is true of a compelled deposition across the street in the middle of the trial must be true of compulsion in pretrial legislative hearings, civil cases, 
the Fifth Amendment.64 Exactly what must be excluded from "a criminal case"? Over the years, courts have been all over the map. As we shall see in more detail later, the earliest American courts addressing the immunity issue required only a narrow form of immunity. ${ }^{65}$ But the U.S. Supreme Court brushed these cases off in its 1892 decision in Counselman v. Hitchcock. ${ }^{66}$ Counselman estab-

grand jury inquests, and so on. (Miranda says that the same should hold for informal compulsion - backed by threatened police brutality rather than formal contempt - in the police station.)

All this is true - except the notion that we have somehow gone beyond the words of the Fifth Amendment. But see Henry J. Friendly, The Fifth Amendment Tomorrow: The Case for Constitutional Change, 37 U. CIN. L. REv. 671, 677 (1968). In all our examples, compulsion may not exist within the criminal case; but the introduction of the compelled statement - the witnessing - does occur in a criminal case, and it is this introduction that violates the Fifth Amendment. This is why out-of-court compelled testimony accompanied by formal or informal immunity simply does not violate the amendment: unless the compelled statement is introduced at a criminal trial, a person has not been made a "witness" (via transcript and videotape) against himself "in" a "criminal case." Although courts and commentators have often been confused - and confusing - on this point, the foregoing appears to be the view of the current Court. See Larry J. Ritchie, Compulsion That Violates the Fifth Amendment: The Burger Court's Definition, 61 MinN. L. Rev. 383, 386, 430 (1977); cf. Michigan v. Tucker, 417 U.S. 433, 440-41 (1971) (declaring that to allow the in-court introduction of testimony created by out-of-court coercion would "practically nullif[y]" the Fifth Amendment privilege); Piemonte v. United States, 367 U.S. 556 (1961) (saying that once proper immunity is offered, no Fifth Amendment violation occurs when a person is forced, upon penalty of contempt, to incriminate himself outside his own criminal case); Brown v. Walker, 161 U.S. 591 (1896) (announcing a similar holding).

Put another way, deposition-like compulsion outside the courtroom is not bad; we use it all the time in civil cases. What is bad is using compelled testimony inside a criminal case for reasons that have to do with the presumptive unreliability of certain types of compelled testimony. See infra section II.E. By contrast, unregulated police-station coercion is often bad in itself and calls for special rules. See infra section II.B.4.

64. In effect, the ability of the government to demand self-incriminating statements in legislative hearings and the like after offering the proper immunity means that - like its Fifth Amendment companion, the Takings Clause - the Self-Incrimination Clause in some ways states a liability rule, not a property rule. See generally Guido Calabresi \& A. Douglas Melamed, Property Rules, Liability Rules, and Inalienability: One View of the Cathedral, 85 HARV. L. Rev. 1089 (1972). Once we see this, we should see the centrality of the scope of immunity: it establishes the all-important fixed price at which the government may buy a person's testimony outside his own criminal case.

Another more nuanced and textual way to see the point is as follows: The clause is absolute, but strictly speaking it applies only to testimony in one's own criminal case. But because one must be able to "take the Fifth" outside criminal cases, see supra note 63, the clause must be enforced by a rule of exclusion within a criminal case. In effect, we have a kind of "liability rule" for "taking the Fifth" in grand jury rooms, civil cases, legislative hearings, and so on - enforceable by a specific performance or "property rule" of exclusion within the criminal case, an exclusion that the government may not "buy off" with money at a judicially fixed price, as with a pure liability rule. But to allow a person outside his own criminal case to ignore all requests to fumish self-incriminating testimony, even after proper immunity has been given, would plainly ignore the textual bounds of the Amendment, which is limited to criminal cases. In effect, it would give a person an absolute right to withhold all testimony, anywhere, anytime, and yet be free from pressure or compulsion. Such a rule is practically unworkable as well as textually implausible. See Piemonte, 367 U.S. at 556; Brown, 161 U.S. at 591.

65. See infra section II.C.

66. 142 U.S. 547 (1892). 
lished an extraordinarily sweeping form of immunity that came to be known as "transactional" because it absolutely prohibited prosecution for any criminal transaction to which a question might relate. ${ }^{67}$ In effect, Counselman prevented a suspect who had been made to sing pretrial from being a witness against himself "in any criminal case" by preventing him from being a defendant - by preventing the case against him from ever going forward. Put another way, Counselman excluded the prosecution itself "in" a "criminal case." But where, textually, does that rule come from? And would its logic require that if a person is made to sing after he has been convicted of a crime, the conviction must be vacated? Does that make sense?68

Formally, Counselman reigned until 1972, but for much of its rule, the so-called dual sovereignty doctrine created an important chink in its armor: before 1964, testimony compelled from a person by federal officials could be used against him in a state prosecution and vice versa. ${ }^{69}$ The Court so held because the Self-Incrimination Clause, and therefore exclusion, applied not to the states but only to the federal government. ${ }^{70}$ With its 1964 decision in Malloy $v$. Hogan, ${ }^{71}$ however, the Court incorporated the clause against the states, rejecting the notion that the Fourteenth Amendment contained "only a "watered-down, subjective version of the individual guarantees of the Bill of Rights." "72 The same day it decided Malloy, the Court reconsidered its rule of self-incrimination dual sovereignty. In light of Malloy, it made little sense that two governments acting in tandem could do what neither could do alone: extort testi-

67. 142 U.S. at 586 ("In view of the constitutional provision, a statutory enactment, to be valid, must afford absolute immunity against future prosecution for the offense to which the question relates.").

68. Although courts might require the convict's compelled statement to harm him in some way to satisfy the requirement that he be a witness "against himself," that requirement might be met easily. Certain avenues of postconviction collateral review - habeas corpus and writs of coram nobis - may in some situations be limited to the factually innocent, and a compelled postconviction confession might undercut a defendant's ability to pursue these postconviction avenues.

69. See Akhil Reed Amar \& Jonathan L. Marcus, Double Jeopardy Law After Rodney King, 95 ColuM. L. REV. 1, 11-15 (1995).

70. See Barron v. Baltimore, 32 U.S. (7 Pet.) 243, 247-49 (1833); see also Feldman v. United States, 322 U.S. 487 (1944) (holding that a defendant's compelled testimony in a state proceeding could be used in federal court to convict the defendant of a federal crime); United States v. Murdock, 284 U.S. 141 (1931) (holding that the federal government need only immunize a witness from federal prosecution and that fear of state prosecution and use of federally compelled testimony will not excuse a refusal to answer).

71. 378 U.S. 1 (1964).

72. 378 U.S. at 10-11 (quoting Ohio ex rel. Eaton v. Price, 364 U.S. 263 (1960) (Brennan, J., dissenting)). 
mony out of court and then introduce it in a criminal case against the testifier. Thus, in Malloy's companion case, Murphy v. Waterfront Commission, ${ }^{73}$ the Court declared that "there is no continuing legal vitality to, or historical justification for, the rule that one jurisdiction ... may compel a witness to give testimony which could be used to convict him of a crime in another jurisdiction."74 According to Murphy, a state witness could not be compelled to give testimony that might be incriminating under federal law unless the compelled testimony and its fruits could not be used in any way by federal officials in a criminal prosecution against him. ${ }^{75}$

Although the Murphy Court cited Counselman, it actually introduced a narrower standard of immunity that was elaborated in a separate opinion by Justices White and Stewart. ${ }^{76}$ Counselman transactional immunity would create huge intersovereign friction: government A could confer immunity and thereby in effect veto government B's law enforcement efforts. To reduce this friction, immunity must be rethought, argued White and Stewart. If only a narrower immunity were required, government B could prosecute even after A's grant of immunity so long as B could prove that all its evidence came from truly independent sources. ${ }^{77}$ (Note, of course, that the difficulty of proving this meant that intersovereign friction would be reduced but not eliminated.78)

Eight years after Murphy, its newfangled immunity rule was formally approved outside the dual sovereignty context in Kastigar $v$. United States. ${ }^{79}$ Unlike Counselman, Kastigar held that the government at times could indeed prosecute a person who had earlier been obliged to testify against himself under a grant of immunity. ${ }^{80}$ Kastigar held that in order to compel incriminating testimony from a witness, the government merely had to grant the witness immunity from the use of his testimony and of its fruits (discoveries made as a result of that testimony) in a criminal trial against him. ${ }^{81}$ This became known as "use plus use-fruits immunity" 82 and is, theoreti-

73. 378 U.S. 52 (1964).

74. 378 U.S. at 77.

75. See 378 U.S. at $78-79$.

76. 378 U.S. at $92-107$ (White, J., concurring).

77. 378 U.S. at 106-07 (White, J., concurring).

78. Here too, we see the "causation gap." See supra note 33.

79. 406 U.S. 441 (1972).

80. See 406 U.S. at 453.

81. See 406 U.S. at $456-59$.

82. Although Kastigar uses the term derivative use to describe this type of immunity, usefruits is more graphic and is used by leading criminal procedure scholars as well as by many 
cally, the standard still in operation today. The Court aimed to find "a rational accommodation between the imperatives of the privilege and the legitimate demands of government to compel citizens to testify" 83 and stated that the new standard "leaves the witness and the prosecutorial authorities in substantially the same position as if the witness had claimed the Fifth Amendment privilege. The immunity is therefore co-extensive with the privilege and suffices to supplant it." 84

In effect, this new rule prevents a suspect from being a witness against himself "in any criminal case" by excluding his words and all things they lead to from the "criminal case." But the Kastigar Court failed to explain persuasively where its new rule came from. Counselman was out, but what, precisely, was the source of Kastigar's "rational accommodation"? How would introducing a physical fact (fruit), but not anything a defendant ever said, make a defendant a "witness" against himself "in" a criminal trial? Kastigar provided few satisfying answers - perhaps because the Court failed to see the huge stakes involved: the entire Fifth Amendment pivots on the precise rule of immunity required. ${ }^{85}$ Beyond its mushy rational accommodation balancing, Kastigar's main argument seems to be that a suspect must be placed in "substantially the same position" whether or not he sings out of court. But this is precisely the "no worse off" test that, as we have seen, is wholly unworkable as a global principle.

Recently, however, even Kastigar has come under attack. Pressure is growing for efficient law enforcement. When an immunized witness is later prosecuted, Kastigar places the burden on the government "to prove that the evidence it proposes to use is derived from a legitimate source wholly independent of the compelled testimony." 86 At times, this burden can be staggering. 87 The government may try to build a Chinese wall between prosecutors exposed

circuits. See, e.g., SALTzBURG \& CAPRA, supra note 30, at 484; United States v. Parker, 848 F.2d 61, 62 n.1 (5th Cir. 1988); United States v. Ingraham, 832 F.2d 229, 238 (1st Cir. 1987); United States v. Perry, 788 F.2d 100, 115-16 (3d Cir. 1986); In re Grand Jury Proceedings Larson, 785 F.2d 629, 630 n.2 (8th Cir. 1986); Grand Jury Subpoena of Ford v. United States, 756 F.2d 249, 253 (2d Cir. 1985).

83. 406 U.S. at 446.

84. 406 U.S. at 462.

85. See supra note 64; see also Baltimore City Dept. of Social Servs. v. Bouknight, 493 U.S. 549 (1990), where the Court dodged the only issue in the case: the scope of immunity, see supra note 54 .

86. 406 U.S. at 460.

87. See Letter from William Treanor to Akhil Amar (December 23, 1994) (on file with authors). Professor Treanor was a prosecutor in the Oliver North investigation. 
to the testimony and prosecutors working on the case against the witness. 88 But sometimes a Chinese wall cannot be built, and sometimes the wall leaks. Another common technique is "canning" the results of an investigation before a potential defendant testifies, ${ }^{89}$ but this involves even greater administrative burdens. To make matters worse, courts have adopted varying interpretations of the independent source standard.

At one extreme is the D.C. Circuit's holding in United States $v$. North. ${ }^{90}$ Oliver North, as many will recall, received a grant of immunity to testify in a congressional hearing involving the IranContra affair. The prosecutor had not seen the testimony, nor did he seek to use it in the prosecution. Several prosecution witnesses, however, had seen the testimony on their own. The court announced that the Fifth Amendment is violated "whenever the prosecution puts on a witness whose testimony is shaped, directly or indirectly, by compelled testimony, regardless of how or by whom he was exposed to that compelled testimony."91 The court imposed additional administrative burdens on prosecutors in its suggestion that the government's burden could be met by "canning the testimony beforehand, just as wise prosecutors meet their burden of showing independent investigation by canning the results of the investigation before the defendant gives immunized testimony." 92 The D.C. Circuit's superstrict approach leaves little difference between use plus use-fruits and transactional immunity.

On the other hand, several circuits have diverged from a superstrict approach, and with good reason. ${ }^{93}$ Besides its sometimes-

88. See United States v. Schwimmer, 882 F.2d 22, 26 (2d Cir. 1989) (recommending the use of Chinese walls); U.S. DePT. OF Justice, U.S. AtTorneys' Manual § 111.40 (1987) (suggesting that prosecution of an immunized witness should be handled by a lawyer unfamiliar with the substance of the witness's testimony).

89. See United States v. North, 920 F.2d 940, $942-43$ (D.C. Cir. 1990) (amending United States v. North, 910 F.2d 843 (D.C. Cir. 1990)). An investigation is "canned" by completing all steps - such as interviewing witnesses, taking depositions, and searching for physical evidence - before immunized testimony is given. Thus the testimony could not have affected the investigation.

90. 920 F.2d 940 (D.C. Cir. 1990).

91. 920 F.2d at 942 .

92. 920 F.2d at $942-43$ (internal quotations and citation omitted).

93. Uses of immunized testimony are divided into two - largely artificial - categories: nonevidentiary and evidentiary uses. Nonevidentiary use generally involves exposure of a prosecutor to immunized testimony. The term is vague and mainly defined by lists of examples. One court has listed the following nonevidentiary uses: "assistance in focusing the investigation, deciding to initiate prosecution, refusing to plea-bargain, interpreting evidence, planning cross-examination, and otherwise generally planning trial strategy." United States v. McDaniel, 482 F.2d 305, 311 (8th Cir. 1973) (finding such uses impermissible). Although the North court did not reach the question of whether nonevidentiary use had occurred because the prosecution had not been exposed to the immunized testimony, the court suggested 
crushing burdens on prosecutors, the D.C. Circuit approach at times can embroil courts in a futile attempt to resolve never-neverland counterfactuals: What would the world look like if Oliver North had never testified? God knows!94 In light of these metaphysical imponderables, why should the law not simply presume irrebuttably - that somehow, some way, the truth and the fruit might have come to light anyway? (This presumption would in effect simply expand the scope of current inevitable discovery doctrine and would track the approaches followed in England and Canada.95) But under this theory, what would be left of use-fruits immunity? Only the testimony itself would be excluded.

In the same way that the Supreme Court in Murphy chipped away at Counselman's transactional immunity before overruling it in Kastigar, the Court is now chipping away at use plus use-fruits immunity in the context of Miranda warnings. When the police interrogate a suspect without giving complete warnings, Miranda bars

that nonevidentiary use was impermissible. See 910 F.2d at 856 . Several courts have come to the opposite conclusion. See United States v. Serrano, 870 F.2d 1, 16-17 (1st Cir. 1989) (stating that Kastigar does not protect against all nonevidentiary uses of compelled testimony because the distinction between use plus use-fruits and transactional immunity would disappear otherwise); United States v. Mariani, 851 F.2d 595, 600 (2d Cir. 1988) (stating that the Fifth Amendment does not "foreclose the prosecution of an immunized witness where his immunized testimony might have tangentially influenced the prosecutor's thought processes"); United States v. Byrd, 765 F.2d 1524, 1530-31 (11th Cir. 1985) (stating that Kastigar does not protect against nonevidentiary uses of compelled testimony such as the decision whether to indict or whether to accept a plea bargain); United States v. Pantone, 634 F.2d 716, 730-31 (3d Cir. 1980) (holding that Kastigar does not prohibit a prosecutor's "mere access to immunized grand jury testimony").

Evidentiary uses - uses that would somehow contribute to the evidence presented at trial - are generally not permitted in Kastigar's regime. The cases revolve around the definition of evidentiary. In North, the D.C. Circuit declared that use of the immunized testimony by witnesses to refresh their memories - a virtually irrebuttable presumption if they were exposed to the testimony - is evidentiary use. See 920 F.2d at 945-46. Again, several courts have disagreed. See United States v. Helmsley, 941 F.2d 71, 82 (2d Cir. 1991) (declining to apply the evidentiary use concept to a witness who may have been exposed to immunized testimony); United States v. Kurzer, 534 F.2d 511, 517 (2d Cir. 1976) (requiring the government to prove merely that the witness's decision to testify was not influenced by immunized testimony).

Different approaches to use immunity are discussed in Jerome A. Murphy, Comment, The Aftermath of the Iran-Contra Trials: The Uncertain Status of Derivative Use Immunity, 51 MD. L. Rev. 1011, 1030-31, 1045-46 (1992) (discussing cases that have differed from the North standard) and Gary S. Humble, Nonevidentiary Use of Compelled Testimony: Beyond the Fifth Amendment, 66 TexAs L. REv. 351 (1987). The North case provoked a legislative effort to overtum it. Senators Joseph Lieberman and Warren Rudman introduced a bill permitting "the use of testimony based on a witness's personal knowledge, regardless of whether the witness has been exposed to the defendant's compelled testimony, as long as such exposure is in no way attributable to the prosecution." Michael Gilbert, Note, The Future of Congressional Use Immunity After United States v. North, 30 AM. CRIM. L. Rev. 417, 434-35 (1993) (citing S. 2074, 102d Cong., 1st Sess., 137 CoNG. Rec. S18,385 (1991)).

94. Yet again, we see a possible "causation gap." See supra notes 33 and 78.

95. See infra section II.C. 
the prosecution from using any resulting confession in its case in chief. However, the Supreme Court has repeatedly chosen to admit the fruits of such confessions. In Michigan $v$. Tucker, ${ }^{96}$ the defendant, arrested for rape, was informed of his right to remain silent and right to counsel, but not of the fact that he would be given counsel if he were indigent. The defendant told the police he was with his friend Henderson at the time of the crime, and the police then questioned Henderson. Henderson's information suggested that Tucker was guilty. His testimony was admitted at trial, over the defendant's objection, and the defendant was convicted. Emphasizing reliability, the Court held that while the failure to give the full Miranda warning required the exclusion of defendant Tucker's statement, it did not require exclusion of his friend Henderson's testimony:

There is plainly no reason to believe that Henderson's testimony is untrustworthy simply because respondent was not advised of his right to appointed counsel. Henderson was both available at trial and subject to cross-examination by respondent's counsel, and counsel fully used this opportunity, suggesting in the course of his cross-examination that Henderson's character was less than exemplary and that he had been offered incentives by the police to testify against respondent. Thus the reliability of his testimony was subject to the normal testing process of an adversary trial. ${ }^{97}$

In Tucker, the Court did not categorically declare that a mere violation of Miranda would always allow use of a confession's fruits, but other decisions seem to be heading that way. In a concurring opinion in New York v. Quarles, ${ }^{98}$ Justice O'Connor advocated a bright-line rule that physical evidence obtained as a result of a confession after a Miranda violation should be admissible. ${ }^{99}$ In Quarles, a woman told police officers that she had just been raped, described her assailant, and said that he had just entered a nearby supermarket and was carrying a gun. One of the officers chased the defendant, who matched the description given by the woman, through the supermarket. The officer caught him and found a holster but no gun; the officer asked him where the gun was, the defendant told him, and the gun was recovered there. The officer then read the defendant his Miranda rights, and the defendant ad-

96. 417 U.S. 433 (1974).

97. 417 U.S. at 449.

98. 467 U.S. 649 (1984).

99. See 467 U.S. at 672 (O'Connor, J., concurring in part and dissenting in part) ("Limitation of the Miranda prohibition to testimonial use of the statements themselves adequately serves the purposes of the privilege against self-incrimination."). 
mitted that he owned the gun. ${ }^{100}$ In the ensuing prosecution for criminal possession of a weapon, the trial judge excluded both the defendant's initial statement of where the gun was and the gun itself.101 Justice O'Connor thought the gun itself should come in: "Admission of nontestimonial evidence of this type is based on the very sensible view that procedural errors should not cause entire investigations and prosecutions to be lost."102 O'Connor relied on the Schmerber line of cases, which emphasized the difference between physical and testimonial evidence, as support for her approach. ${ }^{103}$ Writing one year later in Oregon v: Elstad, ${ }^{104}$ this time for the majority, Justice O'Connor again invoked Schmerber "[t]he Fifth Amendment, of course, is not concerned with nontestimonial evidence"105 - and declined to suppress the fruits of a "mere" Miranda violation. 106 Once again, the Court stressed "the Fifth Amendment goal of assuring trustworthy evidence."107 This approach has led most circuits to embrace the view that all fruits of

100. 467 U.S. at $652-53$.

101. 467 U.S. at $652-53$ (describing the trial court's rulings).

102. 467 U.S. at 673 (O'Connor, J., concurring in part and dissenting in part). Justice $O$ 'Connor emphasized the importance of examining the approaches of countries such as England, India, Scotland, and Ceylon in crafting our own rules regarding confessions and pointed out that the Court in Miranda had explicitly looked to those countries in developing the Miranda rule. She noted that in those countries, "nontestimonial evidence derived from all confessions 'not blatantly coerced' was and still is admitted." 467 U.S. at 673 (O'Connor, J., concurring in part and dissenting in part).

Note that in expressing concern that "entire investigations" not be lost, Justice O'Connor seemed worried about the possibility that, say, the gun might well have been found regardless of the antecedent Miranda violation. See also HENRY J. FRIENDLY, BENCHMARKs 279 (1967) (expressing concern that applying Miranda to fruits would "in effect confer immunity unless the prosecution can meet the burden of showing that its fruits would have been discovered anyway"). Yet again, we see the possible "causation gap." See supra notes 33 and 78.

103. Justice O'Connor stated:

Indeed, whatever case can be made for suppression evaporates when the statements themselves are not admitted, given the rationale of the Schmerber line of cases. Certainly interrogation which provides leads to other evidence does not offend the values underlying the Fifth Amendment privilege any more than the compulsory taking of blood samples, fingerprints, or voice exemplars, all of which may be compelled in an "attempt to discover evidence that might be used to prosecute [a defendant] for a criminal offense."

467 U.S. at 670-71 (O'Connor, J., concurring in part and dissenting in part) (quoting Schmerber v. California, 384 U.S. 757, 761 (1966)). For more discussion of Schmerber, see infra section I.D.

104. 470 U.S. 298 (1985).

105. 470 U.S. at 304.

106. 470 U.S. at 308-09. In Elstad, the "fruit" was itself a statement from the defendant, which the Court found voluntary and reliable even though it was the fruit of an earlier, Miranda-defective utterance.

107. 470 U.S. at 308. 
a (merely) Miranda-defective confession are admissible - even though the confession itself is inadmissible. ${ }^{108}$

But if Miranda is ultimately rooted in the Self-Incrimination Clause, we need to ask what the courts have not (yet) asked: Why not enforce the clause itself by excluding confessions and allowing fruits? ${ }^{109}$

\section{D. "Witness"?}

What does it mean to be a "witness" against oneself? Here, too, the courts have been all over the map.

In the 1886 case of Boyd v. United States, ${ }^{110}$ the Supreme Court held that seizing or compelling production of a defendant's private papers to be used in evidence against him was equivalent to compelling him to be a witness against himself. Boyd's basic rule that a person's property could not be used against him in a criminal proceeding - is plausible in the context of personal papers such as diaries. ${ }^{111}$ A defendant's diary testifies: it speaks in the defendant's

108. See, e.g., United States v. Gonzalez-Sandoval, 894 F.2d 1043, 1048 (9th Cir. 1990) (stating that "the reasoning of Elstad and Tucker applies as well to non-testimonial physical evidence obtained as a result of a Miranda violation"); United States v. Sangineto-Miranda, 859 F.2d 1501, 1514-18 (6th Cir. 1988) (admitting the fruits of mere Miranda violation because "the goal of the fifth amendment's exclusionary rule is to assure trustworthy evidence"); United States v. Bengivenga, 845 F.2d 593, 600-01 (5th Cir. 1988) (finding that a "mere violation of Miranda" does not trigger the exclusion of nontestimonial fruit); United States ex rel. Hudson v. Cannon, 529 F.2d 890, 894-95 (7th Cir. 1976) (holding, in reliance on Tucker and before Quarles, that fruits of a mere Miranda violation should not be excluded).

109. Note how various statements from Justice O'Connor's opinion explicitly speak of the logic underlying not merely Miranda but the privilege against self-incrimination itself. See supra notes 98-108 and accompanying text. Her invocations of Schmerber also sound in pure self-incrimination theory, as distinct from "mere" Miranda concerns. See supra note 103 and text accompanying note 105 .

110. 116 U.S. 616 (1886).

111. On the common law's special solicitude for private papers, see Entick v. Carrington, 19 Howell's State Trials 1029 (C.P. 1765). The idea of what was "private," however, was construed very broadly indeed in certain English cases and went far beyond diaries. See, e.g., Regina v. Mead, 92 Eng. Rep. 119, 119 (K.B. 1703) (refusing to require the defendants, who were charged with executing an office of trust without taking an oath, to produce books showing the election of the corporation's officers because "they are perfectly of a private nature"); Rex v. Worsenham, 91 Eng. Rep. 1370, 1370 (K.B. 1701) (refusing to require the defendants in a forgery case, who were custom-house officers, to produce custom-house books because the books were "a private concern" and therefore requiring production would be "to compel the defendants, to produce evidence against themselves"); Chetwind v. Marnell, 126 Eng. Rep. 900,900 (C.P. 1798) (noting that the plaintiff, in an action brought on a testator's bond that was suspected of being forged, would not be compelled to produce the bond for inspection, if it might be the means of convicting him of a capital felony); The Queen v. Granatelli, 7 Rep. State Trials (New Series) 979, 986 (C.C.C. 1849) (refusing to require a witness, in a prosecution for fitting out a vessel against a friendly power, to produce a sales agreement of the company for which he was secretary because it might incriminate him); see also Roe v. Harvey, 98 Eng. Rep. 302, 305 (K.B. 1769) (Mansfield, L.J.) ("[I]n a criminal or penal cause, the defendant is never forced to produce any evidence; though he should hold it in his hands, in Court."). None of these cases involved immunity statutes, and 
own words, much as would the defendant himself as a witness on the stand.112 Diaries often express secret thoughts that implicate First Amendment concerns and sometimes pose reliability problems because of the use of personal shorthand, fantasy, and so forth.

But not all papers pose these difficulties. In particular, papers kept in connection with legal matters such as taxes or customs duties are quite different. Boyd involved a subpoena requiring the defendant to produce not a diary but books, invoices, and papers for enforcement of customs laws. Boyd's exclusion of such records was inspired by a spirit akin to the spirit of Lochner: ${ }^{113}$ that a person's right to his property includes the right not to have it introduced against him in a criminal case. ${ }^{114}$ (Significantly, Boyd and its immediate progeny involved corporate crime and breaches of regulatory requirements, not violent crime like rape or murder.115)

In a less extreme version of Boyd, many courts in the late nineteenth and early twentieth centuries held that using the defendant's body as physical evidence was in effect compelling the defendant to be a witness against himself. 116 The question, however, was hotly contested; some jurisdictions admitted such evidence. Courts divided on whether a defendant could be compelled to undergo a physical examination, ${ }^{117}$ to make a footprint or fingerprints, ${ }^{118}$ or to

thus none focused on the precise scope of immunity necessary to overcome the selfincrimination privilege.

112. See Telford Taylor, Two Studies in Constitutional Interpretation 67 (1969); Amar, supra note **, at 788.

113. See Lochner v. New York, 198 U.S. 45 (1905).

114. See Amar, supra note **, at 788.

115. See id.; see also William Stuntz, The Substantive Origins of Criminal Procedure 105 YALE L.J. (forthcoming Nov. 1995).

116. One commentator states that excluding such evidence was the majority rule. See Charles Gardner Geyh, The Testimonial Component of the Right Against Self-Incrimination, 36 CATH. U. L. REv. 611, 621 (1987).

117. Compare People v. Akin, 143 P. 795,796 (Cal. Dist. Ct. App. 1914) (refusing to compel a physical examination for venereal disease); State v. Height, 91 N.W. 935,940 (Iowa 1902) (same); State v. Newcomb, 119 S.W. 405,409 (Mo. 1909) (same); Bowers v. State, 75 S.W. 299, 300 (Tex. Crim. App. 1903) (same); People v. McCoy, 45 How. Pr. 216, 217 (N.Y. Sup. Ct. 1873) (refusing to compel a physical examination for evidence of childbirth) with O'Brien v. State, 25 N.E. 137 (Ind. 1890) (holding that the results of a compelled physical examination for scars and identifying marks were admissible); State v. Miller, 60 A. 202 (N.J. 1905) (same); People v. Corder, 221 N.W. 309, 309-10 (Mich. 1928) (allowing evidence of a voluntary physical examination); Noe v. Monmouth, 143 A. 750 (N.J. 1928) (holding that compelling the physical examination of a driver for signs of intoxication was permissible).

118. Compare Cooper v. State, 6 So. 110 (Ala. 1889) (holding that a defendant cannot be compelled to make footprints to have his tracks compared to those found at the scene of the crime); Day v. State, 63 Ga. 668 (1879) (same); State v. Sirmay, 122 P. 748 (Utah 1912) (same) with United States v. Kelly, 55 F.2d 67 (2d Cir. 1932) (permitting the State to compel the defendant to give fingerprints); People v. Jones, 296 P. 317 (Cal. App. 1931) (same; find- 
display himself to the jury or perform physical acts. ${ }^{119}$ Courts adopted various rationales for excluding or allowing the evidence. ${ }^{120}$ The reason for this uncertainty is obvious: using a defendant's body is different in some ways from forcing him to take the stand and testify as a witness, and yet in other ways it does treat him like a witness to be observed by the jury. Is a witness someone who testifies - or merely someone who is observed at trial? To answer this question, we need an overall theory of the SelfIncrimination Clause - and that is precisely what the legal community seems to lack.

As the twentieth century wore on, the spirit of the Lochner era declined, and so did Boyd and its progeny. Beginning with the landmark case of Schmerber $v$. California, ${ }^{121}$ a series of cases in the 1960s and 1970s rejected Boyd's approach. Schmerber, announced a week after the Court's decision in Miranda, gave rise to a sweeping assertion of the need to let in reliable physical evidence, via a definition of witness that drew a sharp distinction between words and physical evidence. The defendant was arrested at a hospital while being treated for injuries from a car accident. A police officer directed a doctor at the hospital to take a blood sample, and an analysis of the alcohol percentage showed that the defendant was intoxicated. The analysis report was introduced at trial, and the de-

ing that fingerprints are not testimonial); Magee v. State, 46 So. 529 (Miss. 1908) (allowing the State to compel a defendant to put his foot in a track found at the scene of a crime, because the compulsion posed no risk to truthfinding).

119. Compare Blackwell v. State, $67 \mathrm{Ga} .76$ (1881) (holding that the State cannot compel a defendant to show an amputated arm at trial); State v. Jacobs, 50 N.C. (5 Jones) 256 (1858) (holding that the State cannot compel a defendant to show himself to the jury for purposes of ascertaining his race); Ward v. State, 228 P. 498 (Okla. Crim. App. 1924) (holding that the State cannot compel the defendant to put on a coat); Turman v. State, 95 S.W. 533 (Tex. Crim. App. 1898) (holding that the State cannot compel the defendant to put a cap on his head) with Ross v. State, 182 N.E. 865 (Ind. 1932) (finding it permissible to compel a defendant to grow a beard); State v. Oschoa, 242 P. 582 (Nev. 1926) (finding it permissible to compel a defendant to show his body to the jurors and to put on a shirt for them); State v. Ah Chuey, 14 Nev. 79 (1879) (holding that a compelled showing of a tatoo does not violate the privilege, because the privilege's purpose is to help find the truth); Sprouse v. Commonwealth, 81 Va. 374 (1886) (finding that requiring a forger to write his name does not violate the privilege).

120. See J.A.C. Grant, Self-Incrimination in the Modern American Law, 5 TeMPLE L.Q. 368, 373-87 (1931); see, e.g., Bruce v. State, 21 S.W. 681 (Tex. Crim. App. 1893). The court in Bruce stated:

[T]he ground upon which this testimony is said to be admissible is that in these cases the physical facts speak for themselves, and no [fears] or hopes of the prisoner could produce or effect a resemblance of his track, or of the wounds or clothing, and their resemblance aids the jury in their search after the truth.

21 S.W. at 682.

121. 384 U.S. 757 (1966). 
fendant was convicted of driving under the influence of alcohol. ${ }^{122}$ Justice Brennan wrote for the Court:

We hold that the privilege protects an accused only from being compelled to testify against himself, or otherwise provide the State with evidence of a testimonial or communicative nature, and that the withdrawal of blood and use of the analysis in question in this case did not involve compulsion to these ends. ${ }^{123}$

In support of the Court's position, Justice Brennan cited Holt $v$. United States, 124 a case where a defendant had been compelled before the trial to try on a blouse related to the crime; the fact that the blouse fit him served as incriminating evidence. The Holt Court, per Justice Holmes, rejected the defendant's objection as "an extravagant extension of the Fifth Amendment;"125 Holmes declared that "the prohibition of compelling a man in a criminal court to be a witness against himself is a prohibition of the use of physical or moral compulsion to extort communications from him, not an exclusion of his body as evidence when it may be material."126 Justice Brennan summed up the distinction thus: "[T]he privilege is a bar against compelling 'communications' or 'testimony,' but . . . compulsion which makes a suspect or accused the source of 'real or physical evidence' does not violate it."127

Although Schmerber did not explicitly overrule Boyd, its logic is hard to square with Boyd's.128 Boyd fused the Fourth and Fifth Amendments together, holding that the two provisions "run almost into each other."129 Schmerber analyzed each amendment separately. ${ }^{130}$ In dissent, Justice Black argued that it was a "strange hierarchy of values" that allowed the state to convict someone with his own blood but not with his "lifeless papers."131 If Black is wrong and Schmerber is right, perhaps the Fifth Amendment is not about privacy, as is the Fourth. And if the two amendments reflect

122. 384 U.S. at $758-59$.

123. 384 U.S. at 761 (footnote omitted).

124. 218 U.S. 245 (1910); see 384 U.S. at 763.

125. 218 U.S. at 252.

126. 218 U.S. at $252-53$.

127. 384 U.S. at 764.

128. See Note, The Life and Times of Boyd v. United States (1886-1976), 76 Mrch. L. REv. 184, 196-98 (1977) (authored by Stan Krauss).

129. Boyd v. United States, 116 U.S. 616, 630 (1886).

130. Compare 384 U.S. at 760-65 (Part II: "The Privilege Against Self-Incrimination Claim") with 384 U.S. at 766-72 (Part IV: "The Search and Seizure Claim"). In each part, Boyd is mentioned only once, and briefiy. See 384 U.S. at 763-64 (reading Boyd as a selfincrimination case about "papers"); 384 U.S. at 768 (reading Boyd as a search and seizure case about warrants and thus as "not instructive" in the case at hand).

131. 384 U.S. at 775 (Black, J., dissenting). 
separate ideas, rather than the same one, then perhaps we should exclude not things - the Fourth Amendment's concern in its "effects" language ${ }^{132}$ - but only words, as in testimonial witnessing, from a criminal case.

But if so, Kastigar unravels. Justice O'Connor in Quarles noted the broad implications of Schmerber and quoted Judge Friendly's view that "[u]se of a suspect's answers 'merely to find other evidence establishing his connection with the crime ... differs only by a shade from the permitted use for that purpose of his body or his blood." "133 O'Connor's own words went one step further: "Certainly interrogation which provides leads to other evidence does not offend the values underlying the Fifth Amendment privilege any more than the compulsory taking of blood samples . . . ."134

Schmerber's progeny continued the division between testimonial or communicative evidence and physical evidence. A series of cases allowed a defendant to be compelled to stand in a lineup, ${ }^{135}$ to give handwriting exemplars, ${ }^{136}$ to give voice-prints, ${ }^{137}$ and to take sobriety tests measuring mental acuity and physical coordination. ${ }^{138}$ Property, too, was no longer sacrosanct. Warden v. Hayden, ${ }^{139}$ which involved the seizure of an armed robber's clothing found in a washing machine in his house, simultaneously rejected the Fourth Amendment mere evidence rule established under Boyd's regime ${ }^{140}$ and reaffirmed Schmerber in holding that because the clothing was not "testimonial" or "communicative," it could be introduced. ${ }^{141}$ Perhaps property protections were not so enticing to the Court when violent crime was involved.

In the 1970s, the Court began to turn away from Boyd even in the context of nonviolent crime and to lessen protection for papers. In a series of cases that all but overruled Boyd, the Court held that even a defendant's subpoenaed papers - except, perhaps, personal papers like diaries - could be introduced at a criminal trial. The

132. U.S. CoNST. amend. IV (affirming the people's right to be secure in their "persons, houses, papers, and effects" (emphasis added)).

133. New York v. Quarles, 467 U.S. 649, 671 (1984) (O'Connor, J., concurring in part and dissenting in part) (quoting FrIENDLY, supra note 102, at 280).

134. 467 U.S. at 670-71 (O'Connor, J., concurring in part and dissenting in part).

135. See United States v. Wade, 388 U.S. 218 (1967).

136. See Gilbert v. Califormia, 388 U.S. 263 (1967).

137. See United States v. Dionisio, 410 U.S. 1 (1973).

138. See Pennsylvania v. Muniz, 496 U.S. 582 (1990).

139. 387 U.S. 294 (1967).

140. 387 U.S. at 306-07.

141. 387 U.S. at 302-03. 
Court's theory was that although they were testimonial, and although their production was compelled, these papers were not compelled testimony within the meaning of the Fifth Amendment because the defendant was not compelled to create the papers in the first place but only to hand them over. ${ }^{142}$ (In this last respect, such papers differed from the "required records" whose creation the government had mandated. ${ }^{143}$ ) If this is the Court's logic, however, it applies to diaries too; so why did the Court pointedly leave this question open? ${ }^{144}$ And in order to decide whether subpoenaed papers are indeed compelled testimony within the meaning of the Fifth Amendment, we need an overall theory of the clause which, again, is precisely what we now lack. Until we have such a theory, it is impossible to decide whether it was the Boyd Court or the modern Court that was playing word games where compelled papers are at issue.

In the end, the Court has been moving away from the overexpansive view of the word witness propounded in Boyd and has sharpened a distinction between compelled words - testimony and physical evidence. This distinction maps onto one common un-

142. See Andresen v. Maryland, 427 U.S. 463, 470-77 (1976) (holding that the introduction at trial of the defendant's business records did not violate the Fifth Amendment because the statements were "voluntarily committed to writing" and were seized pursuant to a valid search warrant); Fisher v. United States, 425 U.S. 391, $402-14$ (1976) (holding that the defendant's Fifth Amendment rights were untouched because he was compelled to produce incriminating papers and not to give self-incriminating testimony); Bellis v. United States, 417 U.S. 85 (1974) (holding that neither a partnership nor its individual partners were shielded on self-incrimination grounds from the compelled production of partnership records); Couch v. United States, 409 U.S. 322 (1973) (holding that a summons served on a taxpayer's accountant requiring him to produce the taxpayer's personal business records in his possession did not violate the taxpayer's Fifth Amendment rights). For more discussion, see Note, supra note 128.

In one respect, the Court has qualified the general rule allowing introduction of subpoenaed documents or other physical evidence. The Fisher Court briefly observed that the act of producing documents itself might have "communicative aspects," such as indicating the taxpayer's belief that those were the documents described in the subpoena, that might be both "testimonial" and "incriminating" for purposes of the Fifth Amendment. See 425 U.S. at 410. But the Court did not attempt to lay down a rule for such cases. In United States v. Doe, 465 U.S. 605, 612-14 (1984) (Doe I), the Court relied on this caveat in Fisher to uphold exclusion of existent documents subpoenaed from the defendant. The Court emphasized, however, that its holding was based on deference to factual findings made by the district court. See 465 U.S. at 613-14. Doe v. United States, 487 U.S. 201 (1988) (Doe II), specified that the privilege applied in cases where producing the evidence would testify to the existence, possession, or authenticity of the things produced. See 487 U.S. at 209.

143. See supra section I.B.3.

144. See Fisher, 425 U.S. at 414 (bracketing the issue of private papers under the Fifth Amendment); Doe I, 465 U.S. at 610 n.7 (repeating Fisher's Fifth Amendment caveat concerning private papers); 465 U.S. at 619 (Marshall, J., concurring in part and dissenting in part) (emphasizing n.7 as leaving open the Fifth Amendment status of private papers). But see 465 U.S. at 618 (O'Connor, J., concurring) (arguing, contrary to n.7, that "the Fifth Amendment provides absolutely no protection for the contents of private papers of any kind"). 
derstanding of the word witness. Witnesses testify; blood does not. The word witness comes from the Old English witnes, meaning "knowledge" (related to the Old English witan, "to know").145 Except in a poetic sense, we do not usually conceive of blood as "knowing" anything. But if this is the key to understanding the privilege, why not exclude the defendant's compelled pretrial testimony (words) but allow in the fruits (physical evidence) that the defendant's out-of-court compelled testimony might lead to?

\section{E. What's the Big Idea?}

What basic rationales underlie the Fifth Amendment? Many discussions by judges and scholars have obscured the privilege behind clouds of eulogy. Over a century and a half ago, Bentham noted that the privilege had long been shielded by an "assumption of the propriety of the rule, as a proposition too plainly true to admit of dispute."146 In his widely influential 1968 Robert S. Marx Lectures, Judge Friendly urged a thorough examination of the policies of the privilege: the task was "indispensable to any reconsideration of the proper scope of the fifth amendment and peculiarly necessary because of the extent to which eloquent phrases have been accepted as a substitute for thorough thought."147

None of the rationales typically given for the Self-Incrimination Clause can satisfactorily explain the current scope of the privilege and its relation to the rest of our legal and moral system. ${ }^{148}$ Sometimes, the idea behind a given rationale is simply wrongheaded. At

145. Webster's ThIRd New InTERnational Dictionary 2627 (1971).

146. 5 JeRemy Bentham, Rationale of Judicial Evidence 229 (London, Hunt \& Clarke 1827).

147. Friendly, supra note 63 , at $679-81,698$.

148. Traditional rationales have long been under attack. Judge Friendly, David Dolinko, and others have convincingly shown that various traditional rationales for the privilege cannot support Fifth Amendment doctrine, at least as it now exists. See Friendly, supra note 63; see also Lewis Mayers, Shall We Amend the Fifth Amendment? (1959); David Dolinko, Is There a Rationale for the Privilege Against Self-Incrimination?, 33 U.C.L.A. L. REv. 1063 (1986); Donald A. Dripps, Foreword: Against Police Interrogation - And the Privilege Against Self-Incrimination, 78 J. CRM. L. \& CRIMINology 699 (1988). Other commentators criticizing the Fifth Amendment over the years have included such luminaries as John Henry Wigmore, Roscoe Pound, and Charles McCormick. See Friendly, supra note 63, at 672-74. Against them are ranged the arguments of Robert S. Gerstein, Privacy and SelfIncrimination, 80 ETHICS 87, 90 (1970) (arguing that individuals should have absolute control over revelations of guilt and remorse); Robert S. Gerstein, Punishment and Self-Incrimination, 16 AM. J. JuRIs. 84, 88 (1971) (similar); Thomas S. Schrock et al., Interrogational Rights: Reflections on Miranda v. Arizona, 52 S. CAL. L. REv. 1, 49 (1978) (claiming that the purpose of the privilege is to enhance autonomy by protecting the individual's right to choose how he "takes responsibility"); Schulhofer, supra note 24, at 330-33 (suggesting that the privilege protects innocent defendants from bad performances on the witness stand); and William J. Stuntz, Self-Incrimination and Excuse, 88 CoruM. L. REv. 1227, 1229 (1988) (arguing that the privilege should properly be construed as protecting "excusable perjury," not merely silence); 
other times, the animating idea is valuable but proves too much or too little (or both) and thus cannot explain why the clause goes as far as it now does but no further.

One frequently mentioned rationale for the privilege is the "psychological cruelty" of the so-called cruel trilemma: without the privilege, the defendant would be forced to choose among selfaccusation, perjury, or contempt. 149 But our justice system has no such scruples about compelling self-damaging answers from a civil litigant both in pretrial discovery and on the witness stand. Nor does our system object to forcing people to testify in criminal cases against friends and family members - except spouses - even though such compelled witnessing can be an extremely painful experience: today a mother may be forced, under penalty of contempt, to testify against her son and send him to the gallows. ${ }^{150}$ Thus, as a descriptive theory, the psychological cruelty argument simply does not hold water. To make matters worse, it benefits only guilty defendants: there is no trilemma if one is innocent and says so. No other criminal procedure provision of the Bill of Rights is designed to give special protection from conviction to guilty defendants. ${ }^{151}$

Courts have also made much of the argument that the Fifth Amendment protects a special zone of mental privacy. ${ }^{152}$ But here

cf. SAltzBuRg \& CAPRA, supra note 30 , at $446-48$ (compiling justifications for the privilege and responses).

149. Murphy v. Waterfront Commn., 378 U.S. 52, 55 (1964); see also Miranda v. Arizona, 384 U.S. 436,460 (1966).

150. Professor Luban argues that the law should recognize broader intrafamily immunity from compelled witnessing. See David LuBan, LAwYERS AND Justice: AN ETHICAL STUDY 197 (1988). But the fact that Anglo-American law has never done this dramatizes the weakness of Luban's account as a descriptive matter. Normatively, a self-incrimination privilege seems much harder to justify than a family privilege: compelling an innocent mother to send her own son to prison or death seems ruthlessly callous, but compelling him to tell the truth and confess seems much less cruel. If he wanted to avoid this cruelty, he could have done so by not committing the crime; his dilemma arises only because he is a criminal.

151. Cf. Amar, supra note **, at 790 n.125. Provisions like the First Amendment do of course protect those guilty of "crimes" like heresy and seditious libel, but these provisions sound in substance, not criminal procedure. As a matter of substantive law, heresy should not be a crime at all; by contrast, the Fifth Amendment applies to things that should be criminal, like rape, murder, and arson. The Eighth Amendment protects the guilty from excessive punishment but not from convictions. The Double Jeopardy Clause does protect the guilty via the plea of autrefois convict, but the clause and its underlying principles provide even more protection to the innocent via pleas of autrefois acquit and collateral estoppel. See Amar \& Marcus, supra note 69, at 36-37. Moreover, autrefois convict only bars multiple convictions of the guilty - in effect, protecting against excessive punishment, see id. at $28-29,36$ \& n.184 - but of course allows the government one unfettered shot at convicting the guilty on the basis of reliable evidence.

152. See Murphy, 378 U.S. at 55; Couch v. United States, 409 U.S. 322, 328 (1973); see also Gerstein, Privacy and Self-Incrimination, supra note 148, at 90-91 (arguing that the selfcondemnation and remorse entailed by incriminating oneself should remain private). Justice 
too, the treatment of civil litigants and witnesses belies this rationale; they are often called to testify concerning intensely private, highly embarrassing matters - in divorce cases, for example. Even in criminal cases, immunity trumps the privilege. A witness given immunity can be forced to testify about anything in his private mental enclave. This treatment stands in dramatic contrast to the true privacy privileges of wife-husband, priest-penitent, doctorpatient, lawyer-client, and so on, for which no such trumping immunity exists.

Related to the notion of protecting mental privacy is the more convincing argument that the privilege helps to protect First Amendment values. But the scope of the privilege on this rationale is overbroad; its literal wording applies not just to political and religious groups but to murderers and rapists as well, whose cases lie far from the core of the First Amendment.

A different possible rationale taps into ideas about parity and symmetry. At the time of the Founding, a defendant was not even allowed to take the stand and testify under oath for himself. 153 Why, then, should the government have been allowed to force the defendant to take the stand and testify under oath against himself? ${ }^{154}$ (Put another way, this disparity might seem to violate the minimal idea of parity underlying the Compulsory Process Clause: the government could compel the defendant to be a witness, but he could not "compel" himself to be a witness. ${ }^{155}$ ) But this logic is

O'Connor, however, has written that the privacy rationale does not apply to suspects in custodial interrogation: "Where independent evidence leads police to a suspect, and probable cause justifies his arrest, the suspect cannot seriously urge that the police have somehow unfairly infringed on his right 'to a private enclave where he may lead a private life.' "New York v. Quarles, 467 U.S. 649, 670 (1984) (O'Connor, J., concurring in part and dissenting in part) (citing Murphy).

153. Defendants were not allowed to testify under oath at trial in America until the midnineteenth century. See generally Joel N. Bodansky, The Abolition of the Party-Witness Disqualification: An Historical Survey, 70 KY. L.J. 91 (1982).

154. See Theodore Barlow, The Justice of Peace: A Treatise Containing the Power and Duty of That Magistrate 189 (London, Lintot 1745) ("[I]t would be hard, and unequal to rack a Man's Conscience with the Religion of an Oath, and make his Discovery tend to his Condemnation, but not allow his Denial on Oath to have any Weight towards his Exculpation or Acquittal."), quoted in Langbein, supra note 2, at 1085 n.157; cf. 3 JoHN Henry Wigmore, Treatise on the Anglo-American System of Evidence in Trials AT COMmon LAW (3d ed. 1940). According to Wigmore,

In view of the apparent unfaimess of a system which practically told the accused person,

"You cannot be trusted to speak here or elsewhere in your own behalf, but we shall use

against you whatever you may have said," it was entirely natural that the judges should employ the only makeweight which existed for mitigating this unfaimess and restoring the balance, namely, [excluding unreliable] confessions.

Id. \& 865(3), at 354 .

155. See supra section I.A; see also Westen, supra note 10, at 119-20 (using the Compulsory Process Clause to buttress the defendant's right to testify); Peter Westen, Order of 
obsolete today. The Court has held that a defendant enjoys a constitutional right to testify on his own behalf. 156 In any event, this rationale could not explain why fruits should be excluded, because no antidefendant fruits asymmetry has ever existed. Defendants in America have always enjoyed a general right to introduce physical evidence or to put on third-party witnesses, even if they learned of these things or persons from the government itself. Indeed, today parity cuts against broad Fifth Amendment claims: if the government is now obliged to supply a defendant with any exculpatory evidence and information it has, why shouldn't the defendant be obliged to supply the government with any inculpatory evidence and information he has? 157

Another foundation of the clause might be "noninstrumentalization" - the notion that government impermissibly disrespects a person when it uses him as the means of his own destruction. ${ }^{158}$ But noninstrumentalization proves too much. The government "uses" persons as witnesses all the time - whether they will or no. In general, the obligation to serve as a witness when necessary to enforce the laws is part of the duty of citizenship; generally, the law is entitled to every person's evidence. ${ }^{159}$ If the government cannot use a person against himself in a criminal prosecution, why may it do so in a civil prosecution against him? And doesn't Schmerber160 legitimate dramatic instrumental use of a person against himself? Though decided by the slimmest of margins in 1966, Schmerber is an absolutely central case today - the rock on which a great many cases and a considerable amount of crime detection policy have

Proof: An Accused's Right to Control the Timing and Sequence of Evidence in His Defense, 66 CAL. L. REv. 935, 985 n.206 (1978) (similar).

156. See Rock v. Arkansas, 483 U.S. 44, 51-53 (1987) (holding that a defendant enjoys a right to testify on her own behalf under the Fifth, Sixth, and Fourteenth Amendments).

157. See United States v. Agurs, 427 U.S. 97 (1976); Brady v. Maryland, 373 U.S. 83 (1963); Abraham S. Goldstein, The State and the Accused: Balance of Advantage in Criminal Procedure, 69 YALE L.J. 1149, 1198 (1960).

158. On noninstrumentalization and government "usings," see generally Jed Rubenfeld, The Right of Privacy, 102 HaRv. L. Rev. 737 (1989); Jed Rubenfeld, Usings, 102 YALE L.J. 1077 (1993); and Jed Rubenfeld, Reading the Constitution as Spoken, 104 YALE L.J. 119 (1995). On the noninstrumentalization idea in the self-incrimination context, see LUBAN, supra note 150, at 194 ("[M]aking me the active instrument of my own destruction signals the entire subordination of the self to the state."). As this Luban quote indicates, individual variations of the noninstrumentalization idea often come equipped with a set of nice distinctions between active and passive use.

159. See 8 WIGMORE, supra note $154, \S 2192$, at 64 ("For more than three centuries it has now been recognized as a fundamental maxim that the public (in the words sanctioned by Lord Hardwicke) has a right to every man's evidence.") Frankly, it is hard to see how mod. em society could operate without this general presumption.

160. Schmerber v. California, 384 U.S. 757 (1966). 
been built. Can anyone now imagine even a single Justice voting that government may not use an arrestee by forcing him to submit to photographing, fingerprinting, and voice tests whose results may be introduced in a criminal court? And if these instrumental uses are okay, why is using testimonial fruits so different on instrumentalization grounds? ${ }^{161}$

Occasionally, courts and scholars invoke notions such as preferring an accusatorial over an inquisitorial system ${ }^{162}$ or achieving a "fair balance" between individuals and the state ${ }^{163}$ to explain the privilege. These phrases, however, are more like slogans that simply restate the rule than carefully considered rationales. At times, the fair balance idea collapses into a sporting theory of justice the idea that we should boost the odds for criminals just to keep the game interesting, above and beyond the valuable and important "handicap" that the government must prove its case beyond reasonable doubt. ${ }^{164}$ And the aversion to inquisitorial schemes cannot explain why the privilege applies only in criminal but not civil cases. What's more, these notions fail to explain the key case of Schmerber: Is it not arguably imbalanced or inquisitorial when a prosecutor may suck blood from her adversary's very veins with needles that invade his body, and then use his own blood to destroy him at trial in a capital case, and then reinject those veins with lethal poison?

Also flawed is the related notion that the government must shoulder its entire burden of proof, or at least its prima facie case, without any help from the defendant. ${ }^{165}$ The moral intuition under-

161. Other problems for noninstrumentalists: Doesn't the government use a suspect as the testimonial instrument of his own destruction when it secretly invades his house (with a warrant), wiretaps his conversations without his consent, and then uses his own words against him in a criminal trial? Or when it subpoenas the defendant to furnish extant documents written in his own hand and then uses those documents at trial? Or when it compels a defendant to authorize (with words) the release of his own bank statements and then uses the authorization and the bank statements to convict him? See Andresen v. Maryland, 427 U.S. 463, $470-77$ (1976); Fisher v. United States, 425 U.S. 391 (1976); Doe v. United States, 487 U.S. 201 (1988) (Doe In).

162. See Murphy v. Waterfront Commn., 378 U.S. 52, 55 (1964).

163. See 378 U.S. at 55.

164. See In re Winship, 397 U.S. 358 (1970). This valuable safeguard does benefit some guilty defendants but only as an incidental byproduct of achieving its direct aim of protecting innocent defendants from erroneous acquittals.

165. See Williams v. Florida, 399 U.S. 78, 108 (1970) (Black, J., dissenting) (arguing that the Florida notice-of-alibi rule violated the Fifth Amendment and claiming that a criminal defendant has a "historical and constitutionally guaranteed right . . . to remain completely silent, requiring the State to prove its case without any assistance of any kind from the defendant himself"); see also Kevin R. Reitz, Clients, Lawyers, and the Fifth Amendment: The Need for a Projected Privilege, 41 Duke L.J. 572, 581-82 (1991) (asserting that defendant retains "the right to doubt the justness" of the state's criminal law enforcement and thus the 
lying this "look ma, no hands" idea is fuzzy -especially in light of the government's heavy burden of proof - and once again, the idea runs afoul of Schmerber and its progeny. In many contexts, government can oblige a defendant to "help" in nontestimonial ways: by showing up at trial, by allowing witnesses to point at him, by making voice prints, by giving up his very blood, and so on. ${ }^{166}$

Courts have also, rightly, shown considerable concern for deterring improper police practices, including physical brutality. But does the current scope of the privilege accomplish this goal? Although the more egregious forms of interrogation abuse such as beatings have stopped, 167 the practices detailed by Simon indicate that intimidation is alive and well in the police station. Far from civilizing 168 the interrogation process, the current interpretation of the Fifth Amendment has driven it underground. Open interrogation of suspects under direct judicial supervision would serve the goal of deterring police abuse far better, as would a better-constructed Fourth Amendment remedial regime for unreasonable seizures of persons. ${ }^{169}$

In addition, courts have stated that the privilege protects an innocent defendant from a bad performance on the stand.170 But as we have seen, the broad scope of the current privilege actually harms the innocent defendant by denying her the Sixth Amend-

right to refuse his aid). Reitz here confuses the First and Fifth Amendments. Of course a defendant has the right to doubt the state - and to say so vigorously and without penalty but the claimed right to withhold information and reliable evidence without penalty simply does not follow.

166. Not surprisingly, Justice Black's dissent in Williams, setting out the "no help from defendant" theory, echoes his Schmerber dissent and indicates that Justice Black understood that to accept Schmerber - as do all the Justices today, presumably - is to reject the "no help" theory. See Williams, 399 U.S. at 111 (Black, J., dissenting) ("[A] criminal defendant cannot be required to give evidence, testimony, or any other assistance to the State to aid it in convicting him of crime." (citing Schmerber, 384 U.S. at 773 (Black, J., dissenting))).

We do not mean to suggest that the government has no initial burden to meet before it can pluck someone off the street and question him or require him to produce evidence. Fishing expeditions are prevented by the Fourth Amendment rule against unreasonable searches and seizures, which typically calls for reasonable suspicion before stopping and questioning, and probable cause before arrest. See infra section II.E.

167. See Simon, supra note 57, at 199 ("Miranda and its accompanying decisions . . . effectively ended the use of violence and the most blatant kind of physical intimidation in interrogations.").

168. A pun is very much intended. We mean here to conjure up a "civilized" process akin to that used today in "civil" law countries and in "civil" pretrial discovery in the United States.

169. Some ideas for bolstering Fourth Amendment remedies are sketched out in Amar, supra note ${ }^{* *}$, at $811-19$.

170. Cf. Murphy v. Waterfront Commn., 378 U.S. 52, 55 (1964); Wilson v. United States, 149 U.S. 60,66 (1893). 
ment right to compulsory process. ${ }^{171}$ Regarding her own performance, the scope of immunity is again too broad; the problem could be solved simply by allowing the defendant to refuse to testify at trial for the jury to hear but eliciting information pretrial that could generate admissible fruit.

Finally, and relatedly, courts and commentators have stressed that coerced statements are unreliable and that the privilege therefore serves the goal of reliability. ${ }^{172}$ This is indeed a worthy goal, and courts have increasingly emphasized it over the past three decades. But if this is the touchstone, again the scope of immunity today is too broad. Why exclude the physical fruits of confessions, when these are quite reliable and often highly probative pieces of evidence?173

In short, the various rationales repeatedly wheeled out to explain the privilege do not fit with the current scope of immunity. ${ }^{174}$ Small wonder, then, that the Self-Incrimination Clause - virtually alone among the provisions of the Bill of Rights - has been the target of repeated analytic assault over the course of the twentieth century from thoughtful commentators urging constitutional amendments to narrow it or repeal it altogether. ${ }^{175}$

In part, the current confusion about the rationale of the privilege stems from historical confusion. In the past six centuries the privilege has reflected several different fundamental ideas. Recent scholarship has displaced the earlier heroic, teleological accounts of

171. See supra section I.A.

172. See, e.g., Michigan v. Tucker, 417 U.S. $433,448-49$ (1974); Murphy, 378 U.S. at 55; GRIswOLD, supra note 32, at 10-19; Schulhofer, supra note 24; see also Withrow v. Williams, 113 S. Ct. 1745, 1753 (1993) (linking the "Fifth Amendment 'trial right" " and Miranda to "the correct ascertainment of guilt" and arguing that "Miranda serves to guard against "the use of unreliable statements at trial." " (quoting Johnson v. New Jersey, 384 U.S. 719, 730 (1966))). But see Tehan v. United States ex rel. Shott, 382 U.S. 406, 415-16 (1966) (rejecting the innocence-protection rationale in the course of refusing to give Griffin retroactive effect).

173. In a thoughtful essay that properly focuses on innocence and reliability, Professor Schulhofer fails to discuss how these rationales argue against current Fifth Amendment fruits doctrine. See Schulhofer, supra note 24, at 330-33.

174. Professor Stuntz's argument that the Fifth Amendment protects "excusable perjury," see Stuntz, supra note 148, is flawed for several reasons. First, it is anachronistic to think that people at the Founding would commit perjury lightly, see infra notes 205-07 and accompanying text, and so Stuntz's argument fails to explain the Framers' vision. Second, it is morally inexcusable to condone lying when the lie merely compounds the liar's underlying crime. Third, Stuntz's argument rests on a faulty Perry-Mason-like view of confessions. Lies are still useful to prosecutors in a variety of ways. See infra notes 191-94, 208, and accompanying text. In fairness to Stuntz, he claims not that his theory is historically rooted or normatively appealing but only that it fits the cases.

175. See supra note 148. 
the privilege's development. ${ }^{176}$ It now appears that the privilege evolved from a maxim of canon law imported from the Continent: nemo tenetur prodere seipsum, "no one is obliged to produce himself."177 Originally, this meant that the duty to reveal all sins at confession, as a condition of absolution, did not entail having to come forward and accuse oneself in court.178 But once a prosecution was initiated and one was accused and called on as a witness, one had to answer truthfully. ${ }^{179}$

The sixteenth- and seventeenth-century incarnation of the privilege, closely related to the medieval version, involved protections against religious intolerance and open-ended fishing expeditions. In England, prerogative courts such as the Star Chamber and the High Commission and ecclesiastical courts used the oath ex officio. ${ }^{180}$ In this procedure, a person could be plucked from the street and forced to swear an oath that he would answer any questions the court might decide to ask him ${ }^{181}$ before any charge had been leveled against him or any probable cause had been shown to justify singling him out. To make matters worse, the purpose of these indiscriminate procedures was often to identify and punish those whose only possible offense was theological disagreement

176. In the past decade, our knowledge of the origins of the privilege has been significantly expanded and perhaps revolutionized. The earlier-received account was built on two works: Wigmore's massive treatise and Levy's heroicizing work, which built on Wigmore's version. 8 WIGMORE, supra note 154, § 2250; LEVY, supra note 20.

177. A variant of the maxim is nemo tenetur accusare seipsum, "no one is obliged to accuse himself." Simeon E. Baldwin, Preliminary Examinations in Criminal Proceedings, 6 A.B.A. REP. 225, 229 (1883); Edward S. Corwin, The Supreme Court's Construction of the Self-Incrimination Clause, 29 MICH. L. REv. 1, 3 (1930). Two recent articles powerfully argue that the nemo tenetur maxim was imported from the Continent for use in inquisitorial procedure, thus casting doubt on Leonard Levy's argument that the privilege was an English invention. See R.H. Helmholtz, Origins of the Privilege Against Self-Incrimination: The Role of the European Ius Commune, 65 N.Y.U. L. REv. 962, 967-69 (1990); Michael R.T. Macnair, The Early Development of the Privilege Against Self-Incrimination, 10 OxFORD J. LEOAL STUD. 66, 67-70 (1990).

178. Langbein, supra note 2, at 1072; Helmholtz, supra note 177, at 982.

179. E.M. Morgan, The Privilege Against Self-Incrimination, 34 MinN. L. Rev. 1, 4 (1949).

180. Coke's early-seventeenth-century discussion of the oath ex officio reveals distrust of its use to uncover thoughts. The Privy Council on a motion from the House of Commons asked Coke and Chief Justice Popham when the oath could properly be administered. As part of their answer, they stated: "No Man ... shall be examined upon secret Thoughts of his Heart, or of his secret Opinion: But something ought to be objected against him what he hath spoken or done." An Oath before an Ecclesiastical Judge ex Officio, in 12 Coke's REP. 26 (3d ed., 1727). They were particularly concerned about questioning involving "heresy and errors of faith." Id. They also objected to the lack of any preliminary showing of suspicion via accusation or presentment or the like. See Corwin, supra note 177, at 7-8.

181. See Mary H. Maguire, Attack of the Common Lawyers on the Oath Ex Officio as Administered in the Ecclesiastical Courts in England, in EsSAYS IN HISTORY AND POurTICAL THEORY 199 (Carl Wittke ed., 1936). 
with the crown. During the sixteenth and seventeenth centuries, the battles over the oath ex officio concerned the subject matter jurisdiction of ecclesiastical courts and the quality of the charge needed before the oath could be given. ${ }^{182}$

The privilege in a more modern form was half-heartedly invoked in late seventeenth-century heresy and sedition trials, but, contrary to Wigmore's account, the privilege was not firmly established at that time. ${ }^{183}$ Rather than emerging in the seventeenth century to protect defendants in sedition and heresy trials, the modern privilege actually grew legs in the late eighteenth century in ordinary criminal trials, both in England and in America. ${ }^{184}$ It is probably no coincidence that it was just at this time that defense lawyers came to be widely used in criminal trials. Now that they had lawyers, criminal defendants could afford to be silent rather than having to conduct their own defenses; for their part, the lawyers must have enjoyed being able to control their cases without interference from their clients' risky testimony. ${ }^{185}$

The privilege in anything like the form we know it today was slow to catch on in America, even after the ratification of the Bill of Rights, and references to the privilege during the ratification debates were few. One reason is that routine pretrial procedure involved questioning of an accused by a magistrate, and the accused was expected to answer. ${ }^{186}$ If he did not and insisted on standing mute in the face of accusations, this refusal to answer could be laid before a later criminal jury for whatever inferences they might

182. Accordingly, in John Lilbume's first trial, in the Star Chamber, his objection was not that he had a right not to answer incriminating questions but that he had a right to a proper accusation before he did so. 8 WIGMORE, supra note 154, \$ 2250, at 291, 298; Corwin, supra note 177 , at 8 . He refused to answer to any matter not included in the information against him. For this he was whipped, pilloried, fined, and imprisoned. With the victory of the parliamentary forces, the Long Parliament abolished the Star Chamber and the High Commission and forbade ecclesiastical courts to use the oath ex officio. For a discussion, see Charles M. Gray, Prohibitions and the Privilege Against Self-Incrimination, in TuDOR RULE AND Revolution 345 (Delloyd J. Guth \& John W. McKenna eds., 1982).

183. Wigmore placed the origin of the modern privilege with Lilburne's assertions in his later trials when he was faced with questions on treason and related charges. Wigmore claimed that the privilege was well established by the late seventeenth century. 8 WIGMORE, supra note $154, \S 2250$, at 298-99. Now, however, the work of several historians suggests that Wigmore's evidence was flawed. See, e.g., Langbein, supra note 2, at 1071-84.

184. Langbein, supra note 2, at 1065-66; Eben Moglen, Taking the Fifth: Reconsidering the Origins of the Constitutional Privilege Against Self-Incrimination, 92 MrCH. L. Rev. 1086 (1994); see also J.M. BeATTIE, CRIME AND THE COURTS IN ENGLAND 1600-1800, at 364-66 (1986).

185. Langbein, supra note 2, at 1066-71.

186. See Moglen, supra note 184 , at 1094-104; Morgan, supra note 179 , at 18-19. 
draw. ${ }^{187}$ In the mid-nineteenth century, police departments emerged and began to take over certain pretrial investigatory functions, relying on informal coercion. The distinction between informal confession at the hands of the police and compelled selfincrimination during formal proceedings was maintained until the 1897 case of Bram $^{188}$ (briefly) and the 1966 case of Miranda (permanently) merged the two.

Amid this tangled history and unconvincing catalogue of traditional rationales for the clause, three key questions about the scope of the clause stand out. First, why does the privilege apply in a "criminal case" but not in a civil case? Second, why does the privilege simply dissolve once immunity is granted, whereas no true privacy privilege - spousal, priest-penitent, doctor-patient, attorneyclient, and the like - likewise dissolves in the presence of immunity? Third, why does the Fifth Amendment bar only compulsory "witness[ing]" rather than "furnishing evidence"? Any adequate theory must explain these three central features of the clause. No current theory does. ${ }^{189}$

\section{The SOlution}

Current Fifth Amendment doctrine is a quagmire. But there is a way out - a road to firm, high ground. To clear up the confusion, we advocate a solution remarkably like the early scope of the privilege, one that borrows a page from current pretrial civil discovery.

Under our solution, the government would be able to compel all persons to testify truthfully in a wide variety of proceedings before the commencement of, or outside, a formal "criminal case" or trial. These venues include grand jury rooms, legislative hearings, civil cases, criminal cases in which someone else is on trial, and depositions organized by prosecutors. The penalty for refusing to answer would be contempt, ${ }^{190}$ and the penalty for lying would be per-

187. See Office of Legal Policy, U.S. Dept. of Justice, "Truth in Cruminal Jus. TICE" SERIEs Report No. 1, The LAW OF PRE-TRIAL INTERRogation (1986), reprinted in 22 U. MrCH. J.L. REF. 437, 482 (1989).

188. Bram v. United States, 168 U.S. 532 (1897) (holding an involuntary confession made to a police official inadmissible).

189. Professor Stuntz claims that his descriptive theory can explain the pattem of current cases. See supra note 174. Whether or not this is so, Stuntz's theory - that one can excusably lie to cover up earlier crimes one has committed - seems historically implausible and morally unattractive. See supra note 174 . On both these grounds, our theory is superior, and it also better fits the Court's recent trends. See infra Part II.

190. A government could choose a less compulsive scheme, of course, such as one that "compelled" answers by allowing a later jury or fact finder to draw adverse inferences from a suspect's pretrial silence in the face of pointed questions. $C f$. supra section I.B. 
jury. ${ }^{191}$ In the case of criminal depositions, this compulsion would take place under judicial oversight, as in the civil discovery system, but with extra protection: the magistrate would physically preside, rather than oversee by remote control. Defense and prosecution lawyers and a court reporter would typically be present. ${ }^{192}$ In highprofile cases, and perhaps ordinary cases as well, the magistrate could preserve a grand-jury-like secrecy by closing the hearing to the public and sealing the deposition. ${ }^{193}$ The prosecution would not be able to introduce compelled out-of-court testimony "in" a "criminal case" unless the defendant knowingly and intelligently consented at trial, with the judge looking on. But virtually all physical evidence and third-party testimony that the defendant's statement

191. If a defendant can be shown to have lied at his deposition, his words - or the fact that he lied - still could not be introduced at his trial for the underlying offense. His words could be introduced, however, in a subsequent prosecution for perjury. This caveat is necessary because otherwise defendants could effectively render the entire deposition process worthless simply by lying. The Supreme Court has adopted a similar rule in holding that immunized grand jury testimony cannot be used for impeachment purposes at the witness's trial involving the matter about which he testified, see New Jersey v. Portash, 440 U.S. 450 (1979); Mincey v. Arizona, 437 U.S. 385 (1978), but it can be used against the witness in a later perjury prosecution, see United States v. Apfelbaum, 445 U.S. 115, 127-32 (1980); Glickstein v. United States, 222 U.S. 139, 141-42 (1911). In effect, a pretrial deposition belps freeze and lock in a suspect's story, and - via the threat of perjury charges - deters posthoc concoctions. Under our proposal, perjury would become a much more significant weapon in the fight against crime - just as the scope of current self-incrimination doctrine creates strong incentives for wiretaps and sting operations. See supra text accompanying notes 4-5. In a case where a suspect lies, a prosecutor may be able to prove perjury even if she cannot prove the predicate offense. If a murder suspect lies about his whereabouts at the time of the murder, for example, a prosecutor may be able to prove he is a liar, even if she cannot prove he is a murderer. In response to our scheme, legislatures might well choose to boost the penalties for perjury.

192. Defense lawyers have traditionally been excluded from the grand jury room, and we would not require their presence there. Unlike a police-station interrogation, there is little risk of violence against a witness, and so a lawyer is not needed on that account. It is in fact quite useful for society to have at least one nonviolent but secret interrogation place, so that individual members of organized conspiracies can be brought in one by one, and their partners in crime will never know for sure whether they ratted or stood mute. (The secrecy of the grand jury room is in effect the wall between prisoners that creates a classic "prisoner's dilemma" to confess the truth.) Defense lawyers, if present in the grand jury room, can actually prevent an underling who wants to tell all from squealing, for the underling's lawyer may really be the agent of the mob boss; such lawyers often help a group of conspirators to maintain a joint stonewall defense. Cf. Pamela S. Karlan, Discrete and Relational Criminal Representation: The Changing Vision of the Right to Counsel, 105 HARv. L. REv. 670, 693-97 (1992). Even in the case of a lone criminal, a defense attorney may at times impede rather than promote the truth-seeking process. See Stuntz, supra note 60, at 1944-54. Because a lawyer-less witness in a grand jury room may be tricked or intimidated by a clever prosecutor into making misleading or inaccurate inculpatory statements, we would not allow these statements themselves to be admitted in a criminal case, unless the defendant so authorized.

193. Preserving secrecy in the magistrate hearing would protect the witness from having to make potentially embarrassing public revelations and would prevent potential jurors in the public from being tainted by preliminary exposure to excludable testimony. 
led to would be admissible. ${ }^{194}$ The defendant could also be subpoenaed to provide anything in his possession, except possibly his intimate personal papers, upon pain of contempt. In a criminal trial the subpoenaed items could be introduced, but the fact that the defendant produced them could not.195

The textual argument is remarkably clean. A defendant cannot be forced to be a "witness against himself" - to testify, with his own words introduced against him - at trial "in [his own] criminal case." Witness here is used in its natural sense, meaning someone whose testimony, or utterances, are introduced at trial. Witnesses are those who take the stand and testify, or whose out-of-court depositions or affidavits are introduced at trial in front of the jury. Indeed, this is exactly how the word witness seems to be used in the companion Sixth Amendment and in the Treason Clause of Article III. ${ }^{196}$ Physical evidence, on the other hand, can be introduced at trial whatever its source - even if that source is a compelled pretrial utterance. A witness testifies but physical evidence does not. A thing is not a witness. Moreover, if person A takes the stand to testify against defendant $B$, this is not the same as forcing $B$ to be a witness against himself, even if B's compelled pretrial statement led the police to learn of A's existence and information. Although our suspect has indeed been forced to testify pretrial, that testimony occurred outside his own criminal case, beyond the earshot of the jury. Unless these words are introduced at trial, a suspect is not a "witness" against himself "in" a criminal "case."

This clean reading makes sense of all the words of the SelfIncrimination Clause and shows how they fit together (and with kindred words of the Sixth Amendment), but it also does much more than that. It flushes out the heretofore elusive rationale of the Self-Incrimination Clause, as best read: reliability. Compelled testimony may be partly or wholly misleading and unreliable; even

194. An additional possibility is to allow a polygraph test to be conducted on the defendant, with the proviso that the results of the test would not be admissible at trial. Polygraph tests, while less helpful in the employment context, have been shown to be of some help in the context of criminal investigations in enabling the police to decide which trails to follow. Office of Techinology Assessment, U.S. Congress, Scientufic Validity of PolyGRAPH TESTING 8, 58 (1983).

195. This last restriction obviates the Court's concern in Fisher, Doe, and Bouknight that the act of producing documents or objects itself has testimonial value. Cf. supra note 142; infra note 276.

196. The Sixth Amendment provides the accused, in all criminal prosecutions, with the right, inter alia, "to be confronted with the witnesses against him" and "to have compulsory process for obtaining witnesses in his favor." U.S. CoNST. amend. VI. The treason provision provides that "[n]o Person shall be convicted of Treason unless on the Testimony of two Witnesses to the same overt Act." U.S. CoNST. art. III, $\& 3$. 
an innocent person may say seemingly inculpatory things under pressure and suspicion and when flustered by trained inquisitors. But physical fruit is far more sturdy and reliable evidence, so it should be brought before the jury. Of course, government investigations and inquisitions implicate issues beyond reliability - of bodily autonomy, of personal privacy and dignity, of freedom of thought and conscience, and so on - but as we shall see, these concerns are best addressed via other constitutional clauses and principles outside the self-incrimination idea.

Our clean reading also solves many of the common-sense conundra plaguing current doctrine. Indeed, our reading achieves almost the same results that Judge Friendly argued for in his wise and influential lectures on the Self-Incrimination Clause. ${ }^{197}$ But whereas Friendly's elaborate analysis led him to propose a sixpronged constitutional amendment of over three hundred words to achieve his sensible results, we reach largely the same conclusions through a more elegant and parsimonious textual analysis of the fifteen words of the existing clause.

\section{A. "Person"}

Under our reading of the clause, the problem of the innocent defendant noted earlier would be solved. There would be no war between the Fifth Amendment privilege and the Sixth Amendment right to compulsory process to obtain witnesses. An innocent defendant could use "compulsory process" (Sixth Amendment) to "compel" (Fifth Amendment) the guilty party to be a "witness" (Fifth and Sixth Amendments) against himself, upon pain of contempt and under penalty of perjury. In short, the guilty could be made to sing and to be subject to withering questioning by defense counsel. The guilty witness's compelled testimony could not be introduced against him in any subsequent criminal trial, unless he authorized admission at trial. But officials would otherwise be free to prosecute, even on the basis of leads (fruits) generated by the compelled testimony.

The Canadians already have a similar rule in cases where the defense calls a witness who claims he might incriminate himself by answering. The witness is required to testify, ${ }^{198}$ but the prosecution

197. See Friendly, supra note 63.

198. Canada Evidence Act, R.S.C., ch. E-10, § 5(1) (1970) (requiring that the witness answer); R.S.C., ch. E-10, $\S 5(2)$ (1970) (prohibiting the prosecution from using testimonial admissions of a witness who objects that he will incriminate himself). A coparticipant must also testify, if he is charged separately from the defendant. Re Regan, 2 D.L.R. 135, 137-38 (N.S. 1939). 
cannot use his testimonial admissions - the words themselves against him in a future proceeding. However, Canada does allow the prosecution to use the fruits of his testimony against him.199

Some might claim there is a textual problem with this interpretation because the Fifth Amendment says "in any criminal case."200 But the key "person" this clause is designed to protect is the "person" on trial - the defendant in his own criminal case. A witness required to testify at someone else's criminal trial with testimonial immunity is in basically the same position as a suspect required to give an immunized deposition for his own trial or to testify in a civil case, in a legislative hearing, before a grand jury, or in any other proceeding. ${ }^{201}$

This testimonial immunity has several advantages over other sorts. Transactional immunity would thwart legitimate law enforcement against the guilty witness, and as a practical matter, so could use plus use-fruits immunity. Under the latter regime, prosecutors would need to prove that they had obtained evidence from independent sources, and, as we have seen, the costs of such a system in terms of lost evidence and administrative burdens can be high. Testimonial immunity, by contrast, would in no way hinder enforcement efforts against the immunized witness: the government loses nothing that it already had or might get independently. On the contrary, by immunizing the witness, an innocent defendant would be helping the police, generating leads that the police would be free to follow to convict the real culprit. The government therefore would have no excuse for denying the innocent defendant's constitutional right of compulsory process.

Because previous courts defined the Fifth Amendment too broadly, they ended up betraying the explicit Sixth Amendment right to compel witnesses. If the Fifth Amendment is restored to its proper scope, a defendant would indeed enjoy a kind of Sixth Amendment parity with the prosecutor. Both could subpoena; both could immunize. This Sixth Amendment right is absolutely essential, for it is truly at the heart of our criminal procedure. It is

199. See Report of the Federay/Provincial TASK Force on UNIForm Rules of EVIDENCE $\S 33.3(\mathrm{~b})$ (1982) (considering and rejecting proposals granting an indicted witness use-fruits immunity); see also Tague, supra note 7, at 3 n.11.

200. See, e.g., Friendly, supra note 63, at 676.

201. Current doctrine, of course, recognizes this too. A person can never be compelled, upon pain of contempt, to witness in his own criminal trial, but he can be obliged - with immunity - to witness in someone else's trial, civil or criminal. This immunity is enforced by a rule of exclusion in his own case. See supra notes 63-64 and accompanying text. The only question is how broad that immunity must be - exactly what must be excluded in his own criminal case. 
nothing less than the right to mount a defense - a right of obvious importance to all defendants and of transcendent significance for truly innocent defendants. ${ }^{202}$ As the Supreme Court put the point in its landmark case, Washington v. Texas:203

The right to offer the testimony of witnesses, and to compel their attendance, if necessary, is in plain terms the right to present a defense, the right to present the defendant's version of the facts as well as the prosecution's to the jury so it may decide where the truth lies. ${ }^{204}$

Some might argue that the right to compel a guilty witness to take the stand would not benefit the innocent defendant very much. The witness would simply lie. Those who framed the Fifth Amendment, however, thought differently. Earlier generations believed that perjury was a mortal sin, resulting in eternal damnation: better to admit murder than commit perjury under oath. ${ }^{205}$ The power of oaths several centuries ago is abundantly clear from the Constitution itself, which requires oaths in two of its most important provisions, ${ }^{206}$ and from landmark opinions of the Marshall Court stressing oaths. ${ }^{207}$

True, times have changed. Perjury has largely lost its religious connotations and is feared mainly for its possible secular sanction. Even today, however, perjury will sometimes be a more severe penal threat than the underlying crime, and if our solution were adopted, legislatures might choose to increase the maximum punishment for perjury. What's more, as noted above, the witness need not confess all on the stand for his testimony to be vital to an innocent defendant. Simply forcing a witness to tell his story can be invaluable. The innocent defendant then would have the opportunity to demolish it with questions and other evidence that might otherwise be excluded for lack of foundation. Prosecutors today, for example, get considerable mileage out of a suspect's lies. Alibis, denials, and explanations "can be checked and rechecked until a suspect's lies are the greatest evidentiary threat to his freedom."208

202. See generally Westen, supra note 10 , at 182-84.

203. 388 U.S. 14 (1967).

204. 388 U.S. at 19 (emphasis added).

205. See BARLOw, supra note 154, at 189 (stating that oaths "might serve instead of the Rack, to the Consciences of some Men, although they have been guilty of Offenses"), quoted in Langbein, supra note 2, at 1085 n.157.

206. See U.S. CoNST. art. II (elaborating the presidential oath); U.S. CoNST. art. VI, cl. 3 (requiring officeholders to take an "Oath or Affirmation" to support the Constitution).

207. See Marbury v. Madison, 5 U.S. (1 Cranch) 137, 180 (1803) (stressing the judicial oath); McCulloch v. Maryland, 17 U.S. (4 Wheat.) 316, 416 (1819) (authorizing Congress to add new oaths).

208. Simon, supra note 57, at 198. 


\section{B. "Compelled"}

\section{In-Court Compulsion}

Compared to the current morass, the compulsion line in our solution would be easier to enforce. Pretrial, a suspect under our scheme must comply with all judicially authorized depositions, inquests, and subpoenas. If he does not, he could be made much worse off: held in contempt and punished. At trial, the judge would exclude the defendant's compelled pretrial testimony, unless the defendant affirmatively authorizes its introduction as evidence. And for the reasons we identified above, courts could continue to follow the nice compulsion rule laid down in Griffin concerning incourt inferences about in-court silence. ${ }^{209}$ The Self-Incrimination Clause, as best read, is designed to protect a truly innocent defendant who might be made to look guilty on the stand by a clever prosecutor skilled in technical courtroom procedure and forensics. To infer guilt from mere in-court silence would seem to betray the innocent but unpersuasive defendant whom the clause seeks to protect. 210

Prosecutors could probably encourage the defendant to take the stand at trial or to authorize introduction of pretrial statements with bribes, such as recommendations of reduced jail time. The baseline of compulsion would be established by the burden of proof rules at trial, the definition of elements of the offense, the statutory sentence authorized, and the Griffin rule itself. These would fix a Coasean starting point from which defendant and prosecutor could bargain. ${ }^{211}$ In contrast to the situation at the Founding, ${ }^{212}$ today the Court has recognized the defendant's right to testify under oath; the innocent defendant is able to calculate the risk that his testimony will be misinterpreted, and this screening will help make the testimony that the defendant voluntarily authorizes to be admitted in court more reliable.

209. See supra section I.B. But see OfFice of Legal Policy, U.S. Dept. OF Justice, REPORT TO THE ATtORNEy GENERAL ON ADVERSE INFERENCES fROM SilenCe, No. 8 (1989), reprinted in 22 U. MrCH. J.L. REF. 1005, 1078-81 (1989).

210. See infra section II.E.

211. This in-court inducement to testify differs arguably from much out-of-court compulsion by the police, in that the prosecutor is merely trying to persuade the defendant to testify - simply to take the stand - while the police often encourage a suspect to testify against himself - to confess, to provide a certain substantive slant. The latter leads to more reliability difficulties. It is useful here to note that a defendant's testimony is voluntary even when it is shaped by various strategic considerations.

212. See supra text accompanying note 153 . 
Under this logic, the "silence penalty" imposed by the Sentencing Guidelines should pass constitutional muster. Griffin is neatly distinguishable: there is a world of difference between using (thenunreliable) silence to prove guilt before guilt has been independently established and using silence once guilt has already been otherwise proved. Put another way, by the time the Guidelines are applied, they penalize moral culpability on the underlying offense, rather than silence per se. If the Guidelines' common-sense morality is to be upheld on this theory, however, the logic of the SelfIncrimination Clause must sound in reliability, as we explain in more detail below. 213 After a successful appeal, a defendant may have a right to insist that his earlier-induced statements be excluded from the guilt-determination phase of the retrial - because, in law, he reverts back to presumptive innocence and Griffin thus applies. (In effect, his earlier-induced testimony is protected by our rule of testimonial immunity.) But in this second trial, as in the first, the Sentencing Guidelines' silence penalty remains in effect, constituting a lawful Coasean bribe to induce the defendant to (again) waive his "starting point" right of silence.

\section{Out-of-Court Compulsion: Government Employment}

Currently, the government, when acting as an employer, is caught between a rock and a hard place. It must choose either to act sensibly as an employer ${ }^{214}$ or to act efficiently in its sovereign capacity as law enforcer. ${ }^{215}$ Instead, the government should be put in the same position as any other employer. It should be able to fire stonewalling employees and otherwise to act as a normal employer, without detriment to its law enforcement function. The only way to guarantee no detriment is to allow all fruit in, thereby avoiding the burdens of Chinese walls, "canning," North-style acquittals, and so on.

But what about the out-of-court testimony itself? When could it come in? The issue here is cloudier - and the stakes are much lower once fruits may come in - but one clear rule would be that the limits on the power of the government-as-employer over its employees should be the limits on the power of normal employers. (Private standards of coercion, such as laws against extortion,

213. See infra section II.E.

214. It could do so by immunizing its employees, making them sing, and then taking appropriate employment action in light of their song.

215. It could do so by refusing to confer sweeping immunity that might compromise later criminal prosecutions. 
would apply.) Under this theory, courts could hold that no impermissible Fifth Amendment compulsion exists from reasonable employment decisions because no one is compelled to work for the government in the first place. If statements made under threat of dismissal are reliable enough to come in when dismissal is threatened by a private employer, why not for a public employer too?216 (Note that in asking the "How much pressure is too much pressure?" question, we now have a touchstone: reliability. ${ }^{217}$ ) Any action beyond these limits should be construed as impermissible coercion, with the result that the coerced statement itself — but not the fruits - would be excludable. This, in effect, would treat coercion beyond responsible employment sanctions exactly the same as coercion in depositions, hearings, and the like. Deposition coercion is backed by contempt and imprisonment - powers no private party enjoys - and so the coercion in depositions is clearly the coercion of a "sovereign." The same should be true when a government employer acts more coercively than a reasonable private employer would; in effect, leveraging its sovereign power in the employment context is an "unconstitutional condition."218

\section{Out-of-Court Compulsion: Required Records}

In required records cases the Court has adopted a balancing approach to the privilege, unwarranted by constitutional text, in order to avoid the substantial burdens imposed by, and the broad logic underlying, Kastigar's use plus use-fruits immunity. That form of immunity would have practically foreclosed any prosecution of Bouknight for child abuse 219 and prevented the police from discovering the identity of, and therefore prosecuting, the hit-and-run

216. Cf. Friendly, supra note 63 , at 707-08 (drawing an analogy between public and private employers).

217. See infra section II.E.

218. The argument here is not that government employment action is not state action, nor that mimicking the market can never violate constitutional provisions, such as the First Amendment. Rather, it is that market mimicry should not be understood as the kind of compulsion that offends the letter or spirit of the Self-Incrimination Clause. This conclusion is not the product of unreflective labels about "natural baselines" distinguishing between government as "sovereign" law enforcer and government as "mere" employer; but instead it follows Professor Sunstein's invitation to reflect self-consciously on the "baseline" that best vindicates a particular provision's purposes. See Cass R. Sunstein, Lochner's Legacy, 87 Colum. L. REv. 873 (1987); Cass R. Sunstein, Why the Unconstitutional Conditions Doctrine is an Anachronism (With Particular Reference to Religion, Speech, and Abortion), 70 B.U. L. REv. 593 (1990). For an earlier exposition that makes very similar points, see Westen, Incredible Dilemmas, supra note 15.

219. See Baltimore City Dept. of Social Servs. v. Bouknight, 493 U.S. 549 (1990). 
driver in Byers. ${ }^{220}$ The Court responded by creating exceptions to the privilege in the Shapiro-Byers-Bouknight line of cases. But the need for such exceptions shrinks dramatically if one gets at the root of the problem: the scope of immunity.

Under our solution, required records, just like any other compelled, incriminating statement, would generally receive full Fifth Amendment protection. They themselves could not be introduced "in" a "criminal case" - that is, at trial - but any fruits they led to could be introduced.221 Thus, the body of the child in a case like Bouknight would have to be produced and could be introduced in the trial of his abuser, but not the fact that the defendant's information led to him. The hit-and-run driver could still be prosecuted. The quandary the Court currently faces - possibly making the government worse off as criminal law enforcer whenever it needs records for legitimate noncriminal purposes - would thus be elegantly solved. ${ }^{222}$

220. See California v. Byers, 402 U.S. 424 (1971); see also Shapiro v. United States, 335 U.S. 1 (1948); supra section I.B.3.

221. This interpretation of the Fifth Amendment arrives at Judge Friendly's solution without the need for a constitutional amendment. Friendly advocated "[r] equiring registration or reporting reasonably necessary for a proper governmental purpose, provided that no registration or report so compelled shall be admissible as evidence of any crime revealed therein." Friendly, supra note 63 , at 722 . But, he argued, "the government should not be forced to show it would have been able to prosecute quite apart from the information furnished by the registration or report or be prohibited from using leads obtained therefrom." Id. at 720 .

222. Even with this quandary solved, however, the required records doctrine still presents thorny issues. Sometimes, the government will need to introduce the records themselves to get a conviction. At least two theories are plausible here. First, if a required record is of a type a person would have kept anyway, the government could make a kind of inevitable discovery argument as follows: the defendant would have kept the record voluntarily, so the government did not really "cause" or "compel" its creation, and it should be subject to subpoena under Fisher v. United States, 425 U.S. 391 (1976), with immunity provided merely for the testimonial act of compelled production itself. See infra text accompanying notes 275-76. This theory builds on Justice Harlan's first prong in Marchetti v. United States, 390 U.S. 39 (1968), discussed supra in section I.B.3, but tries to give it more rigor. (Even if a new, noncustomary record is required as a condition of doing a certain kind of business, perhaps the government could also argue here that no real Fifth Amendment compulsion exists, because a person is free not to engage in that business. Cf. supra section II.B.2.) Second, it might be argued that certain kinds of records, required of broad classes of persons not suspected of criminal wrongdoing, and not involving face-to-face encounters with interrogators, need not be seen as akin to criminal "witnessing" even though these records are testimonial and ultimately introduced in a criminal case. This theory repackages Justice Harlan's third Marchetti prong as a textual argument about "witness" and reflects the Big Idea that at the Founding compelled criminal witnessing would often be unreliable because of the imbalance of power, interruptions, traps, and the like in face-to-face exchanges between citizens and prosecutors. See infra section II.E. We do not necessarily embrace either theory here; their elaboration must await another day.

Note finally that corporate required records have long been given only minimal Fifth Amendment protection. See Hale v. Henkel, 201 U.S. 43, 75 (1906) ("While an individual may lawfully refuse to answer incriminating questions unless protected by an immunity stat- 


\section{Out-of-Court Compulsion: Police Interrogation}

Our deposition approach would limit abusive police tactics. The basic insight uniting pre-Warren Court voluntariness cases like Brown v. Mississippi $i^{223}$ and Warren-era landmarks like Miranda ${ }^{224}$ and $E s c o b e d o^{225}$ would be preserved and strengthened: we need to rein in unsupervised police officers who might be tempted to abuse suspects. The best way to do this is to shift interrogation from police stations to magistrates' hearing rooms. On the civil discovery side, we generally do not try to get damning admissions from defendants by using third-degree tactics. We use subpoenas and depositions with lawyers, loosely supervised by judges. ${ }^{226}$ Miranda failed to require the use of lawyers, magistrates, and recorders and from a civil libertarian perspective, this has been its undoing. Miranda also failed to create strong incentives for suspects to talk and to tell the truth - and from a crime control perspective, this has been its undoing. The deposition model would combine both perspectives: the suspect would be protected from abuse and intimidation but must answer truthfully.

The question of how to treat confessions that are obtained by police outside the formal deposition-like process remains. ${ }^{227}$ Fortunately, our solution would make the problem much less pressing because the stakes would shrink: a civilized process would exist outside the police station to compel suspects to talk truthfully, and so the police would be less tempted to force the issue. In light of this civilized alternative, courts might well choose to police the po-

ute, it does not follow that a corporation, vested with special privileges and franchises, may refuse to show its hand when charged with an abuse of such privileges.").

223. 297 U.S. 278 (1936).

224. Miranda v. Arizona, 384 U.S. 436 (1966).

225. Escobedo v. Illinois, 378 U.S. 478 (1964).

226. In civil discovery, magistrates are not typically present during depositions but oversee the general deposition process. In our proposal, magistrates would generally be physically present for criminal depositions of suspects. See supra text accompanying notes 192-95.

227. Rogue police behavior will call for special remedies, including punitive damages against the police department and strict administrative disciplinary mechanisms to punish abusive officers. An appropriate remedial regime is sketched in Amar, supra note **, at 81116. Neither the Fourth Amendment, nor the Fifth, properly construed, requires exclusion of reliable fruits of unreasonable seizures of persons. Moreover, since, in theory, a suspect can be lawfully obliged to truthfully tell all to a magistrate under our approach, the fruits should have come to light anyway and thus would fall under the "inevitable discovery" doctrine, see infra section II.C. Legislatures, of course, would nonetheless be free to require exclusion if they were determined to "teach the cops a lesson." But since abusive cops must be punished and deterred even when they expect to find no evidence, and (unsurprisingly) find no evidence, exclusion is not constitutionally sufficient. A proper punitive damage and administrative disciplinary scheme, by contrast, is both constitutionally necessary and constitutionally sufficient - it protects the innocent but avoids windfalls for the guilty. 
lice even more strictly than today, enforcing a prophylactic rule that no police-station confession by a defendant is ever allowed in, unless volunteered by a suspect in the presence of an on-duty defense lawyer or ombudsman in the police station, or unless the defendant consents to its introduction at trial. Rooted in a legitimate concern about unsupervised police compulsion, this strict regime would create powerful incentives to conduct interrogation before magistrates rather than in police stations.

On the other hand, more relaxed schemes are also compatible with our approach. For example, each suspect in custody could be told that he must be brought before a magistrate and a lawyer within a short time (say, five hours) and that he has an absolute right to remain silent until then; but he should also understand that if he stands mute until then, a later jury can be told of his premagistrate, pre-lawyer silence and might view more skeptically any story he later tries to offer at trial. The range of possible police station schemes compatible with our model is hardly unique or embarrassing. Rather, it reflects the fact that the Self-Incrimination Clause historically addressed formal testimonial compulsion in judicial settings, and so applying the clause to the informal compulsion of the modern police station requires creative adaptation of Founding principles.

And however we regulate the police station itself, nice problems will arise concerning suspects' statements and silences before stationhouse custody commences - at the scene of the crime, on the street corner, in the squad car, and elsewhere. The wide variety of these encounters may well mock any effort at comprehensive rulemaking. But, in keeping with our treatment of employment compulsion, we propose one global rule of compulsion: reasonable adverse inferences from suspicious silence outside courtrooms need not always be treated as Fifth Amendment "compulsion."228

\section{C. "In Any Criminal Case"}

Textually, the Fifth Amendment speaks to witnessing within the criminal case, not beyond. Therefore, the key question is what "witnessing" is excludable "in" a "criminal case" - that is, at

228. Again, silence in the face of some kinds of informal accusation may be far more suspicious than silence in certain formal, legalistic, forensic judicial settings. See supra notes 23, 31. But see supra note 211. See also Jenkins v. Anderson, 447 U.S. 231, 243 (1980) (Stevens, J., concurring) (stating that jurors may draw a "reasonable inference from [suspicious pre-arrest] silence in a situation in which the ordinary citizen would normally speak out"). 


\section{trial.229 This question is the same as what the scope of immunity}

229. Pretrial proceedings are not best read as included within a Self-Incrimination Clause "case." The clause is concerned with a "witness" in a "case" who in effect testifies before the jury. Miranda does not hold otherwise. To be sure, it holds that the Self-Incrimination Clause applies to pretrial police compulsion, but only because the clause applies to all sorts of compulsion outside a criminal case. See supra note 63. The rule of exclusion, however, exists within a criminal case, see id., and Miranda does not hold that the police station is somehow a courtroom. Escobedo does contain language linking police stations and courtroom rights, but later Supreme Court cases broke with Escobedo here, and Escobedo's language, read literally, is hard to take seriously. See Henry J. Friendly, The Bill of Rights as a Code of Criminal Procedure, 53 CAL. L. REv. 929, 946-47 (1965). A police station is not a courtroom, and nothing is tried there. There is no judge, no jury, no public, no confrontation right, and no compulsory process right; and if a right of counsel exists in the police station, it is best understood as a due process right, not a Sixth Amendment right. See id at 944-46; see also United States v. Gouveia, 467 U.S. 180, 187-88 (1984) (holding that the Sixth Amendment right to counsel does not attach until the initiation of formal adversary criminal proceedings); Moran v. Burbine, 475 U.S. 412, 428-30 (1986) (following Gouveia and finding no Sixth Amendment right to counsel in a police station).

Nor does the grand jury proceeding fall within a Self-Incrimination Clause "case." Typically, a grand jury sits before an indictment has issued and often before a clear suspect has emerged. Historically, persons were obliged to tell all in a grand jury hearing, with testimonial immunity enforced only in a later criminal trial. See infra text accompanying notes 23435. In Article III, the word case refers not to a factual transaction but to formal legal proceedings with parties to a lawsuit: a "case" begins when a prosecutor or plaintiff files an indictment or complaint. Indeed, the word case is linked to the word cause, as in a formal legal "cause of action." See Akhil Reed Amar, Law Story, 102 HARv. L. Rev. 688, 718 n.154 (1988). Functionally, it does not make much sense to bar postindictment depositions while allowing preindictment hearings, because indictments could often be postponed or dismissed in order to conduct the desired depositions. The key exclusion is thus exclusion of testimony from the trial, where the jury sits to find the facts.

This notion of what a Self-Incrimination Clause "case" is fits with the way we apply rules of evidence, such as hearsay. Rules of evidence, of course, apply at trial - but they do not apply in pretrial proceedings such as depositions and grand jury hearings. See FuEMiNO JAMES, JR., ET AL., CrvII PROCEDURE § 5.3, at 238 (4th ed. 1992) (stating that at a deposition the matter inquired into "need not itself be admissible evidence"); see also Costello v. United States, 350 U.S. 359 (1956) (refusing to quash an indictment based exclusively on hearsay testimony). Like the privilege against compelled self-incrimination, rules of evidence such as hearsay are meant to improve reliability. Reliability of individual bits of information is critical at trial, where final decisions are made, but not so critical where the goal is simply to gather as much relevant information as possible before sifting, as in pretrial proceedings. The different burdens of proof at the pretrial and trial stages - probable cause for an indictment as opposed to proof beyond a reasonable doubt for a criminal conviction - lead to differences in the need for rules emphasizing reliability. See infra section II.E; $c f$. United States v. Williams, 112 S. Ct. 1735, 1743 (1992) (suggesting that evidence previously obtained "in violation of the privilege against self-incrimination" may be used in the grand jury, but not in a criminal trial, a suggestion that would be hard to sustain if the grand jury were itself a "case" within the meaning of the Self-Incrimination Clause).

Note finally that the question is not whether the word case must mean "at trial but not before" but whether it most sensibly should mean this to achieve maximum textual coherence, structural harmony, common sense, and so on. Our reading of the word case enables the words of the Self-Incrimination Clause to fit together and make good policy sense; it coheres with the idea of "witness" "in" a "case"; it fits with the cognate words and principle of the Sixth Amendment, which is about "witnesses" at trial (there is no right to confront grand jury witnesses or those who give investigators pretrial statements that are never introduced at trial); it meshes tolerably with the wording of Article III; and it draws support from American history. See infra text accompanying notes 233-49. Overall, this is more than other readings of case can do, especially when unsupported by a clear and coherent theory of the overall meaning and purpose of the Self-Incrimination Clause. 
should be. The Kastigar ${ }^{230}$ rule for "true" Fifth Amendment violations - use plus use-fruits immunity - should be trimmed back and brought into line with Justice O'Connor's suggested approach in Quarles 231 for "mere" Miranda violations. Compelled testimony should be excluded from a criminal case - unless the defendant authorizes its introduction at trial — but not fruits. A rule excluding compelled testimony would be much easier to enforce than the Kastigar rule excluding fruits - a rule that has led to many difficult issues of proof, but-for causation, and never-neverland counterfactuals, as in the North case. A statement by the defendant is selfidentifying, but other physical evidence and witnesses are not: they do not come with "courtesy of defendant" labels stating how the government got them or whether the chain of causation ran through the defendant's pretrial statements. The recurrent friction between different government authorities with the power to grant immunity (states, federal prosecutors, Congress, and so on) that led the Court in Murphy 232 to move toward Kastigar would be eliminated. If government A grants immunity, government $B$ would be no worse off. Currently, A can to some extent veto B's law enforcement by imposing North-like litigation burdens on B requiring it to prove it got all its evidence independently. So the very same internal logic that drove the Court in Murphy from Counselman to proto-Kastigar should now drive it all the way home to a Quarles-like rule.

Testimonial immunity also has some important history on its side; it is consistent with many courts' view of the privilege before the Counselman decision in 1892. Prior to Counselman, case after case in state after state and in lower federal courts held that the privilege was satisfied by excluding compelled pretrial testimony but not the fruits of that testimony.233 Before 1892, the leading American case was People v. Kelly, ${ }^{234}$ decided by New York's high-

230. Kastigar v. United States, 406 U.S. 441 (1972), discussed in supra section I.C.

231. New York v. Quarles, 467 U.S. 649, 660-74 (1984) (O'Connor, J., concurring in part and dissenting in part), discussed in supra section I.C.

232. Murphy v. Waterfront Commn., 378 U.S. 52 (1964), discussed in supra section I.C.

233. See New York ex rel. Hackley v. Kelly, 24 N.Y. 74 (1861); infra note 238 (citing cases). Early manuals for justices of the peace also stressed testimonial immunity for pretrial examinations, which were routine. A Georgia manual announced: "No man shall be compelled to give evidence against himself. Hence it is that if a criminal be swom to his examination taken before a justice, it shall not be read against him." Augustin S. CLAYTON, THE Office and Duty of A Justice of the PeAce 132 (Milledgeville, Ga., S. Grantland 1819) (emphasis added).

234. New York ex rel. Hackley v. Kelly, 24 N.Y. 74 (1861). Early federal cases shed little light on the scope of the privilege. The most often cited is the opinion of Chief Justice Marshall in United States v. Burr, 25 F. Cas. 38 (C.C.D. Va. 1807) (No. 14,692e). In Aaron Burr's trial for high treason, the prosecution sought to examine Burr's secretary, a Mr. Willie, about 
est court in 1861. Kelly involved a witness called by a grand jury and asked to answer incriminating questions. The court held that as long as the compelled testimony was excluded from any subsequent criminal trial against the witness, the privilege was satisfied.235 In addressing the argument-that the privilege required broader immunity, the court announced:

[N]either the law nor the Constitution is so sedulous to screen the guilty as the argument supposes. If a man cannot give evidence upon the trial of another person without disclosing circumstances which will make his own guilt apparent or at least capable of proof, though his account of the transactions should never be used as evidence, it is the misfortune of his condition and not any want of humanity in the law.... [T]he statute makes it impossible that his testimony given on that occasion should be used by the prosecution on the trial. It cannot, therefore, be said that in such a criminal case he has been made a witness against himself . ...236

This rule was widely followed among the states; in his opinion in Kelly, Judge Denio observed that "[i]f the case is so situated that a repetition of [the witness's admission] on a prosecution against him is impossible, as where it is forbidden by statute, I have seen no authority which holds or intimates that the witness is privileged."237

whether he understood a letter in code. Willie objected, claiming his Fifth Amendment privilege and suggesting that he feared prosecution for misprision of treason. After hearing argument on the point for two days, the Chief Justice required Willie to answer, on the somewhat flimsy basis that the question only referred to current knowledge of the code, and current knowledge would not justify an inference that Willie knew the code at the time the letter was sent. 25 F. Cas. at 40. Marshall went on to state a general rule that "the court ought never to compel a witness to give an answer which discloses a fact that would form a necessary and essential part of a crime which is punishable by the laws." 25 F. Cas. at 40 . United States $v$. Burr was quoted at length in Counselman v. Hitchcock, 142 U.S. 547, 565-66 (1892), but the case does not support the Counselman, or even the Kastigar, position. There were no immunity statutes at the time, and so Marshall's opinion does not concern the scope of immunity. Anything Willie said in Burr's trial could be repeated against him at Willie's subsequent trial. If Willie's testimony were considered self-incriminating, compelling him to testify in Burr's case would have been tantamount to compelling him to testify against himself in his own case. Thus, in Marshall's era, the key question was not the scope of immunity but the definition of self-incriminating. Marshall's broad language does not apply to a world where a witness can be given testimonial immunity. (Interestingly, Marshall's holding is far narrower than his language. Willie was compelled to answer after all. Marshall's definition of selfincriminating could be quite narrow in practice.)

The later merging of the rule against coerced confessions and the privilege against selfincrimination makes Marshall's language all the more obsolete. See infra note 249. When a coerced confession occurred, the words were excluded from the defendant's trial but the fruits came in.

235. 24 N.Y. at 84. The New York Constitution of 1846 tracked the federal Fifth Amendment virtually word for word. See N.Y. Const. art. I, \& 6 (1846) (amended 1938, 1949, 1959 $\& 1973$ ) ("No person ... shall ... be compelled in any criminal case, to be a witness against himself ....").

236. 24 N.Y. at $83-84$ (emphasis added).

237. 24 N.Y. at 83-84. 
Numerous immunity statutes providing for testimonial but not usefruits immunity were upheld. 238

Furthermore, testimonial immunity was Congress's idea of the scope of the privilege at the time of Kelly. ${ }^{239}$ An 1857 act provided broad transactional immunity for anyone who "shall be required to testify before ... Congress."240 Senator Trumbull criticized the scope of immunity as too sweeping, allowing "the greatest criminal [to] escape."241 Subsequent events confirmed Trumbull's fears, ${ }^{242}$ and the Act was pointedly amended in 1862 to read simply: "The testimony of a witness ... . shall not be used as evidence in any criminal proceeding against such witness." 243 Congressional debate over this bill "shows conclusively" that Congress believed that the Constitution required only testimonial immunity. ${ }^{244}$ Senator Benjamin Wade described the scope of immunity under the new statute with crystal clarity:

238. For federal cases upholding such statutes, see, for example, United States v. McCarthy, 18 F. 87,89 (C.C.S.D.N.Y. 1883) (relying on Kelly for proper interpretation of the privilege and scope of immunity) and In re Counselman, 44 F. 268 (C.C.N.D. Ill. 1890), revd sub nom. Counselman v. Hitchcock, 142 U.S. 547 (1892). The Counselman court held:

If, through threats or fears of violence, a man confesses that he has committed murder, and states who was present at the time, and where the weapon and the dead body may be found, and he is afterwards put on his trial for the offense, he cannot be confronted with his confession; but the person who saw the crime committed is a competent witness, although the prosecutor might never have known there was such a witness but for the confession, and it may be shown by others that the weapon and dead body were found where the defendant said they could be found.

44 F. at 271. For state cases, see, for example, Ex parte Rowe, 7 Cal. 184 (1857) (upholding a testimonial immunity statute); Higdon v. Heard, $14 \mathrm{Ga} .255,259$ (1853) (holding that immunity satisfies the federal constitutional privilege if the answers given by witnesses "cannot be read in evidence against them, in any criminal case whatever"); Bedgood v. State, 17 N.E. 621, 623-24 (Ind. 1888) (holding that a testimonial immunity statute fully guarantees the privilege); Wilkins v. Malone, 14 Ind. 153, 156-57 (1860) (holding that facts revealed by immunized testimony may be proved against the witness in his later criminal trial, "although the confessions are wholly inadmissible," and that even if the fruit comes in, so long as the testimony is excluded, "the party cannot be said, in any just sense, "to be compelled to testify against himself' in the criminal prosecution"); Ex parte Buskett, 17 S.W. 753, 754-55 (Mo. 1891) (relying on Kelly and holding that a witness is not protected from the introduction of the fruits of immunized testimony); Lathrop v. Clapp, 40 N.Y. 328, 332 (1864) (approving a testimonial immunity statute after Kelly); LaFontaine v. Southern Underwriters Assn., 83 N.C. 132, 141-43 (1880) (relying on and quoting Lathrop).

239. Not all federal immunity statutes were as clear as the Act of 1862, discussed infra text accompanying notes 243-46. For a list of the relevant statutes, see J.A.C. Grant, Immunity From Compulsory Self-Incrimination in a Federal System of Government, 9 TEMP. L.Q. 57,64 n. 47 (1934).

240. Act of Jan. 21, 1857, ch. 19, § 2, 11 Stat. 155, 156.

241. Cong. GLobe, 34th Cong., 3d Sess. 437 (1857); cf. United States v. North, 920 F.2d 940 (D.C. Cir. 1990), discussed in supra text accmpanying notes 90-92,

242. See Cong. Globe, 37th Cong., 2d Sess. 364, 428-29 (1862).

243. Act of Jan. 24, 1862, ch. 11, 12 Stat. 333.

244. Grant, supra note 239 , at 64 . 
You may inquire; [a witness] may testify and may be compelled to testify [out of court], but whatever he says shall not be used as evidence against him in any court. That is all that a rascal ought to have at the hands of justice....

... [I]f his [out-of-court] testimony is given, though it cannot be used directly against him, it may lead to other testimony that may throw light on the subject, whereby in the concatenation of events he may be convicted of crime. Well, sir, I hope it will be so. ${ }^{245}$

This was Congress's understanding of the privilege at the time it proposed the Fourteenth Amendment, making the Bill of Rights applicable against the states and reglossing the federal provisions. 246 (This clear understanding and legislative history loom especially large in light of the absence of much clarity or legislative history underlying the initial adoption of the Self-Incrimination Clause in the 1780 s.)

The early and middle nineteenth century, the period in which the above cases were decided and narrow immunity statutes adopted, is the key period in the development of the modern privilege. Once defense lawyers began to be widely used in the late eighteenth and early nineteenth centuries, defendants at trial could keep quiet and let their lawyers speak for them - as is the case now. ${ }^{247}$ As the privilege began to take hold in the pretrial phase of magistrate examination, the criminal justice system needed a way to find out what happened - to tap the suspect as a valuable testimonial resource. ${ }^{248}$ Immunity statutes proved to be the answer, and they sprang up in abundance during this period. ${ }^{249}$ This is also the

245. Cong. Globe, 37th Cong., 2d Sess. 429 (1862).

246. See Akhil Reed Amar, The Bill of Rights and the Fourteenth Amendment, 101 YALE L.J. 1193 (1992). On the "feedback effect" of the Fourteenth Amendment on a proper understanding of the original Bill of Rights and its limits on federal power, see id. at 1281-82.

247. See Langbein, supra note 2.

248. See id. at 1055.

249. Note that under our regime, in which truthful answers are required under threat of punishment but (testimonial) immunity is automatically granted, immunity statutes are technically unnecessary. The privilege becomes self-executing; compelled self-incriminating statements are automatically excluded from the person's own criminal trial. The privilege thus operates exactly like the common law rule excluding coerced confessions. So why were immunity statutes thought to be necessary in the midnineteenth century? Because, formally, the rule against coerced confessions and the privilege against compelled self-incrimination were distinct legal doctrines. See supra text accompanying note 188. Coerced confessions made outside the courtroom were automatically excluded from one's own criminal case, but testimony within courtrooms was not. Before immunity statutes, therefore, courts had no way to threaten courtroom witnesses with punishment if they did not answer and still preserve the privilege. (The trial of Aaron Burr illustrated the difficulties of trying to get selfincriminating testimony from a witness in the pre-immunity-statute era. Indeed, Chief Justice Marshall strained the definition of non-self-incriminating testimony to get Willie's testimony in. See supra note 234.) But Miranda merged the two doctrines. See supra text accompanying note 188 . After the merger, any compelled self-incriminating statement, whether made inside or outside a courtroom, would automatically trigger immunity, without 
period that saw the emergence of professional police charged with systematic investigation of crime. Thus, it was in the early and middle nineteenth centuries that courts and legislatures hammered out the true scope of the modern privilege.

Unfortunately, the U.S. Supreme Court in Counselman chose to follow those few cases that called for transactional immunity rather than the large number that supported testimonial immunity. Wigmore noted only three cases before Counselman that required immunity broader than testimonial;250 all three of these involved state constitutional provisions that, unlike the federal Fifth, protected against being compelled to give "evidence" against oneself. The most influential of these was the Massachusetts case Emery v. Commonwealth. 251 The second followed Emery and involved a very broad protective immunity statute, ${ }^{252}$ and the third was later questioned by the court that initially decided it. 253 Indefensibly, the U.S. Supreme Court in Counselman followed Emery, which was based explicitly and self-consciously on the peculiar wording of the Massachusetts Constitution, and rejected Kelly, which was based on a New York provision that tracked the Federal Constitution virtually word for word. ${ }^{254}$ When Kastigar effectively overruled Counselman, the Supreme Court adopted a new standard - use plus

the need to invoke immunity statutes. (A finding that the statement had been compelled formally or informally - would of course still be necessary.) Courts have been unwilling to recognize this logic under the regimes of transactional and use-fruits immunity because those immunities are so broad, so they have clung to the requirement of immunity statutes. But, with testimonial immunity, practice can be reconciled with theory.

250. 8 WigmoRE, supra note $154, \S 2283$, at $527 \&$ n.6.

251. 107 Mass. 172,182 (1871). Emery explained that because the Massachusetts Constitution forbade that one "be compelled to accuse, or furnish evidence against himself," 107 Mass. at 180 (emphasis added), the privilege was broader in Massachusetts than in New York and protected a witness "so long as he remains liable to prosecution criminally for any matters or causes in respect of which he shall be examined or to which his testimony shall relate." 107 Mass. at 185 . The case thus required transactional immunity.

252. The highest court of New Hampshire followed Emery in State v. Nowell, 58 N.H. 314,314 (1878), which required transactional immunity. The court noted that the New Hampshire constitution provided that no one "shall . . . be compelled to accuse or furnish evidence against himself." 58 N.H. at 314 (quoting N.H. CoNST. art. I, \& 15 (emphasis added)). In addition, the New Hampshire immunity statute was very broad; it provided that "no testimony ... given by [the witness] shall, in any prosecution, be used as evidence, either directly or indirectly, against him, nor shall he be thereafter prosecuted for any offence so disclosed by him." 58 N.H. at 315 .

253. The Virginia Supreme Court required transactional immunity in Cullen v. Commonwealth, 65 Va. 624,633 (1873). The Virginia Bill of Rights stated that no one could "be compelled to give evidence against himself." VA. CoNsr. art. I, \& 8. In any event, Cullen was questioned by a member of the court in Temple v. Commonwealth, 75 Va. 892, 902 (1881).

254. See Counselman v. Hitchcock, 142 U.S. 547, 586 (1892). The Court noted the differences in the wordings of the federal and Massachusetts constitutional provisions but stated that "there is really, in spirit and principle, no distinction arising out of such difference of language." 142 U.S. at 586. 
use-fruits immunity - but offered no good reason for failing to return to Kelly's testimonial immunity. 255 In short, Fifth Amendment doctrine today is the unconvincing and half-hearted residue of an 1870s opinion from Massachusetts that explicitly relied on state constitutional phrasing that the Federal Fifth Amendment impliedly rejected.

Counselman also relied on the landmark Boyd case, ${ }^{256}$ whose Fourth and Fifth Amendment mishmash has now been emphatically rejected. Indeed, Boyd's role as the godfather of Counselman is visible in two of Boyd's key - and now repudiated - passages. The first fused together the Fourth and Fifth Amendments:

We have already noticed the intimate relation between the two amendments. They throw great light on each other. For the "unreasonable searches and seizures" condemned in the fourth amendment are almost always made for the purpose of compelling a man to give evidence against himself, which in criminal cases is condemned in the fifth amendment. ${ }^{257}$

The second also explicitly read the Fifth Amendment as if it prohibited compulsion to "furnish evidence" and implied that all criminal subpoenas of a defendant violated the Fifth. ${ }^{258}$ But these two interpretations were decisively renounced by the Supreme Court in United States v. Leon ${ }^{259}$ and Fisher v. United States, ${ }^{260}$ respectively. In each of these cases, the Court used the same phrase: Boyd had not stood "the test of time."261

Counselman also rejected the English rule, which was testimonial immunity. In the coerced confession context, which Miranda merged into the Self-Incrimination Clause, this rule was firmly established in the 1783 case The King $v$. Warickshall. ${ }^{262}$ In Warickshall, the defendant, charged with being an accessory after the fact

255. Ironically, New York's highest court repudiated Kelly as a result of the Counselman decision. See People v. O'Brien, 176 N.Y. 253 (1903) (requiring transactional immunity and explicitly following Counselman).

256. Boyd v. United States, 116 U.S. 616 (1886).

257. 116 U.S. at 633 (emphasis added).

258. 116 U.S. at 637 (stating that the subpoena in this case "is surely compelling [the defendant] to furnish evidence against himself" (emphasis added)).

259. 468 U.S. 897, 905-06 (1984) (citing Boyd's Fourth-Fifth Amendment fusion progeny).

260. 425 U.S. 391, 408 (1976) ("[T] the compelled production of every sort of incriminating evidence but applies only when the accused is compelled to make a testimonial communication that is incriminating.").

261. Leon, 468 U.S. at 906 ("The Fifth Amendment theory has not withstood critical analysis or the test of time ... ."); Fisher, 425 U.S. at 407 ("Several of Boyd's express or implicit declarations have not stood the test of time.").

262. 168 Eng. Rep. 234 (K.B. 1783). 
for knowingly receiving stolen property, made a confession because of "promises of favour,"263 which in those days was rightly considered to be a coerced confession. ${ }^{264}$ In her confession, she revealed where the stolen goods were hidden, and so they were found in her mattress in her lodgings. The question to be decided was whether the stolen goods and their location could be admitted into evidence; the court held that they were admissible. The court stated with assurance:

[T] his subject has more than once undergone the solemn consideration of the Twelve Judges; and a majority were clearly of the opinion, That although confessions improperly obtained cannot be received in evidence, yet that any acts done afterwards might be given in evidence, notwithstanding they were done in consequence of such confession. ${ }^{265}$

Coerced confessions, said the court, were unreliable, but the fruits here posed no reliability problem. ${ }^{266}$ To exclude these fruits simply in order to prevent a suspect from being "made the . . . instrument of her own conviction" would be "novel in theory," "dangerous in practice," and "repugnant to the general principles of criminal law."267 This was apparently the leading English case on point when the U.S. Bill of Rights was adopted in 1791.

\section{168 Eng. Rep. at 234.}

264. The crown witness system was a major force leading to the rule against coerced confessions. John H. Langbein, Shaping the Eighteenth-Century Criminal Trial: $A$ View from the Ryder Sources, 50 U. CHI. L. REv. 1, 105 (1983). Under this system, witnesses were granted immunity from prosecution if they testified against their partners in crime. If several gang members tried to become crown witnesses, the one who could reveal the most was granted immunity. This led to contests between gang members to tell all, and more than all. Incentives to lie were great, because the crimes involved usually carried the death penalty. If a suspect tried and failed to become a crown witness, his confession could and would be used against him. Thus the exclusionary rule for tainted confessions was born of a concern for reliability.

265. 168 Eng. Rep. at 235 (footnote omitted). The court emphasized: "The rules of evidence which respect the admission of facts, and those which prevail with respect to the rejection of parol declarations or confessions, are distinct and independent of each other." 168 Eng. Rep. at 235. In America, it was hombook law as late as 1960 that courts would not exclude the fruits of coerced confessions. See 2 Francis Wharton, Wharton's Criminal EVIDENCE $\S \S 357-58$ (Ronald A. Anderson ed., 12th ed. 1955); 3 WIGMORE, supra note 154, \$ 856-59; Yale Kamisar, Wolf and Lustig Ten Years Later: Illegal Evidence in State and Federal Courts, 43 MiNN. L. REv. 1083, 1115 n.109 (1959). In fact, we are aware of no U.S. Supreme Court case - before or after 1960 - that actually excludes physical fruits of a coerced confession that occurred outside formal proceedings. Miranda does contain an ambiguous sentence about fruits, see 384 U.S. 436, 479 (1966) (speaking of "evidence obtained as a result of interrogation"), but that sentence has since been repudiated. See supra section I.C. But cf. Wong Sun v. United States, 371 U.S. 471, 484-88 (1963) (excluding, on Fourth Amendment grounds, physical evidence as fruit of illegal arrest).

266. 168 Eng. Rep. at 235.

267. 168 Eng. Rep. at 234 (emphasis added). Note the court's explicit and emphatic rejection of a broad noninstrumentalization theory. 
Seventy years later, in The Queen v. Leatham, ${ }^{268}$ the English judges made clear that a similar result applied to self-incrimination under formal immunity statutes: only testimonial immunity, not transactional or use plus use-fruits immunity, was required. In Leatham, decided under an immunity provision of the Corrupt Practices at Elections Act, the defendant's immunized testimony before election commissioners led to discovery of a preexisting letter that was introduced against him at his subsequent trial for bribery. The court held that only the defendant's statements should be excluded and that the letter was admissible. Crompton J. noted:

In the analogous case of confessions by persons accused of crimes, they cannot be used against such persons if obtained from them under the compulsion of a threat, or the inducement of a promise; but matters to which such a confession gives a clue may nevertheless be unexceptionally put in evidence. For instance, if stolen goods or a murdered body are or is found in a place indicated by the confession, this fact may be given in evidence. ${ }^{269}$

Several judges mentioned the great difficulties involved in administering a rule of use plus use-fruits immunity. As Crompton put the point, a legislative grant of use-fruits immunity

would have introduced great inconvenience, giving rise in every case to the necessity for an inquiry, in all subsequent proceedings, as to whether or not the clue which led to them was obtained from something let fall by the defendant when before the Commissioners, and thereby opening as wide a field for investigation as can possibly be conceived. 270

The problems noted by Crompton would be avoided by restoring the narrow scope of the privilege and allowing fruits to come in. This result could also be reached by simply expanding the Supreme Court's inevitable discovery doctrine, expounded in Murray $v$. United States. ${ }^{271}$ The fruits could have come to light anyway, so the

268. 121 Eng. Rep. 589 (Q.B. 1861).

269. 121 Eng. Rep. at 593 (Crompton, J.). Contemporaneous American cases explicitly following the same logic in the self-incrimination/testimonial immunity context include Wilkins v. Malone, 14 Ind. 153, 156-57 (1860) and In re Counselman, 44 F. 268, 271 (1890), revd sub nom. Counselman v. Hitchcock, 142 U.S. 547 (1892).

270. 121 Eng. Rep. at 592-93 (Crompton, J.); see also 121 Eng. Rep. at 594 (Blackburn, J.) ("[A]n enactment that nothing, the first clue to which was given by a witness under examination by the Commissioners, should be provable against him by evidence aliunde, would have been very unwise; would have encouraged rather than checked the corrupt practices which the Act seeks to put a stop to; and would have introduced excessive practical inconvenience ....").

For further statements of the English rule of testimonial immunity, see Commonwealth $v$. Knapp, 26 Mass. (9 Pick.) 495, 510-11 (1830) and 1 J.F. ARChBold, Practice, Pleadino, AND Evidence In CRIMINal CASEs 424 (Thomas W. Waterman ed., 7th ed. 1860).

271. 487 U.S. 533, 536-44 (1988). The Canadians have a well-developed inevitable discovery doctrine and draw sharp distinctions between physical evidence and testimony for 
argument would go, and the presumption to that effect would be irrebuttable.

\section{D. "Witness"}

Schmerber ${ }^{272}$ was right to emphasize the distinction between testimony and physical evidence, but later decisions have failed to follow its logic to the end. Only the defendant's compelled testimony should be protected by the Amendment. The "witnessing" that the defendant has a right to exclude from the criminal trial includes both communicating on the stand at trial and introducing at trial any earlier compelled depositions. This definition of witness closely tracks what seems to be the best definition of witness under the Confrontation and Compulsory Process Clauses of the Sixth Amendment. ${ }^{273}$ Unlike some state constitutions, such as the Massachusetts Constitution of 1780 , the Fifth Amendment does not prohibit the government from compelling a defendant to "furnish evidence against himself." 274 Compelled fruit is admissible, but compelled testimony is not.

purposes of exclusion. See R. v. Collins, [1987] 1 S.C.R. 265, 284 (Can.) (Lamer, J.) ("Real evidence that was obtained in a manner that violated the Charter [constitutional protections against self-incrimination, unreasonable search and seizure, and so on] will rarely operate unfairly for that reason alone. The real evidence existed irrespective of the violation of the Charter and its use does not render the trial unfair."); Mellenthin v. Regina, [1992] 3 S.C.R. 615 (Can.) (drawing a distinction between real evidence that the defendant has been forced to create by constitutional infringement and real evidence that the defendant has been forced to locate or identify by constitutional infringement, and also distinguishing between independently existing evidence that could have been found without compelled testimony and independently existing evidence that would have been found without compelled testimony); Black v. Regina [1989] 2 S.C.R. 138 (Can.) (holding that physical evidence obtained as a direct result of a statement taken in violation of a defendant's right against self-incrimination is admissible where the evidence would have been uncovered by the police in any event). The author of a leading Canadian treatise has noted the "overwhelming tendency of our courts to characterize any tangible evidence such as weapons or drugs as real evidence not going to the faimess of the trial and hence, under the Collins regime, generally admissible." Don Stuart, Charter Justice in Canadian Criminal Law 401 (1991). He does cite a few exceptions, however, mainly in cases where the constitutional violation was "flagrant." Id. at 406-07, 414.

272. Schmerber v. California, 384 U.S. 757 (1966).

273. A sensible definition is found in Justice Thomas's concurrence, joined by Justice Scalia, in White v. Illinois, 502 U.S. 346, 358 (1992). This definition includes "any witness who actually testifies at trial" and anyone who gives "extrajudicial statements ... contained in formalized testimonial materials, such as affidavits, depositions, prior testimony, or confessions." 502 U.S. at 365 (Thomas, J., concurring). The extension to extrajudicial statements prepared for trial is analogous to the Self-Incrimination Clause's application to out-of-court compulsion. See supra note 63 . Obviously, the government should not be able to evade a defendant's right to confront government witnesses by recessing a trial, walking across the street and deposing a witness without the defendant or his lawyer present, and then returning to court and introducing into evidence a transcript and videotape of the deposition. $C f$. $i d$.

274. Compare U.S. Const. amend. V with MAss. Const. pt. I, art. XII (1780) ("furnish evidence against himself") and PA. CoNsT. art. I, $\$ 9$ (1776) ("give evidence against himself"). Several other state constitutions use the phrase give evidence. See 8 WIGMORE, supra 
Fisher, ${ }^{275}$ too, fits our approach. Obliging a suspect to hand over incriminating words or things already in existence can be distinguished from obliging him to be a witness - to testify in response to clever questions put by a prosecutor. As we shall see, testimony extorted by clever prosecutors can raise distinct reliability concerns - prosecutors tricking suspects into misleading and hasty concessions that look like confessions - that are not generally present when a suspect is merely obliged to hand over an already extant object (with testimonial immunity for the act of handing over itself). ${ }^{276}$

Two borderline questions noted earlier remain concerning defendants' bodies and diaries. First, what, if any, protections should a defendant have if the prosecution would like to use his body, rather than his communications? ${ }^{277}$ The answer lies in the Fourth Amendment, not in the Fifth. The use of a defendant's body as physical evidence is not testimonial, and therefore it is not covered by a privilege that protects a person from "witnessing" against himself. But the Fourth Amendment guards against "unreasonable searches and seizures" of "persons," and its protections should be applied in these situations. ${ }^{278}$ Properly construed, the requirement of "reasonableness" invites judges to engage in balancing the state's and the individual's interests;; clude the gravity of the offense charged, the invasiveness or humiliation of the examination or act, and the importance of the evidence to the prosecution's case.280 (Unlike the Fifth Amendment, the

note $154, \S 2252$, at $321-24$ n.3. Wigmore thought that these differences were "immaterial" and that "[t]hese various phrasings have a common conception, in respect to the form of the protected disclosure." 8 id. $\$ 2263$, at 362 . However, Wigmore thought that New York's Kelly case should be the uniform rule. 8 id. $\$ 2283$, at 525-28.

275. Fisher v. United States, 425 U.S. 391 (1976), discussed in supra section I.D.

276. Under testimonial immunity, the subpoenaed object could be used at trial but not the testimonial fact that defendant supplied the object. This clean rule contrasts dramatically with the Kastigar regime, under which the proper scope of "act of production" immunity is a huge unsolved - and perhaps metaphysically insoluble - puzzle. To get a sense of the Kastigar complexities here, see Kenneth J. Melilli, Act-of-Production Immunity, 52 OHo ST. L.J. 223 (1991); Reitz, supra note 165, at 618-27.

277. See supra section I.D.

278. In the lineup case of United States v. Wade, 388 U.S. 218 (1967), Justice Fortas articulated a rationale that sounds like a Fourth Amendment, not a Fifth Amendment, interpretation: the lineup was "an incident of the State's power to arrest, and a reasonable and justifiable aspect of the State's custody resulting from arrest." 388 U.S. at 260 (Fortas, J., concurring).

279. See Amar, supra note **, at $801-11$.

280. If the defendant refuses to comply, there are several options available. Depending on the circumstances, the defendant could either be held in contempt or evidence of the refusal could be introduced at trial. See South Dakota v. Neville, 459 U.S. 553 (1983). There, the Court held that "a refusal to take a blood-alcohol test, after a police officer has lawfully 
Fourth Amendment approach would protect a person's body even in civil cases - indeed, especially in civil cases.) Under this approach, courts are free to distinguish sensibly between, say, a painful and intrusive stomach pumping and a quick and virtually painless taking of a blood sample. 281

Second, what protection should diaries enjoy? Unlike bodies, diaries are clearly communicative and testimony-like. At a minimum, the search for and seizure of diaries should be governed by a Fourth Amendment reasonableness test. This test should be informed by the probability that a search for a diary will be intrusive, the broad freedom of thought principles of the First Amendment, and the special treatment the Fourth Amendment accords to "papers."282 What's more, reading a person's diary (even if lawfully obtained) in open court, civil or criminal, can be seen as an additional invasion of privacy - an incremental "search" of a man's soul, an additional "seizure" of a woman's most intimate secrets that once again calls for a careful judicial inquiry into the reasonableness of this public reading. ${ }^{283}$ Above and beyond these Fourth Amendment concerns is a key Fifth Amendment concept - reliability. Writers of diaries often fantasize or write in a personal shorthand easily misinterpreted. Though not compelled testimony in exactly the same way that forcing the witness to take the stand is compelled testimony, diaries may raise sufficiently distinct reliability issues to justify treating them differently from all other voluntarily created documents that the government wants to search for or subpoena.284 Therefore, we can see why the Court has intuited that diaries might differ on Fifth Amendment grounds from, say, voluntarily created business records. ${ }^{285}$

requested it, is not an act coerced by the officer, and thus is not protected by the privilege against self-incrimination." 459 U.S. at 564 . Moreover, the officer was not required to give warnings that evidence of refusal might be introduced at trial. 459 U.S. at 566.

281. Compare Rochin v. California, 342 U.S. 165 (1952) (invalidating stomach pumping) with Schmerber v. California, 384 U.S. 757 (1966) (upholding the taking of blood). See also Winston v. Lee, 470 U.S. 753 (1985) (disallowing unnecessary surgery).

282. See Amar, supra note **, at 806-07; see also TAYLOR, supra note 112, at 66-68; Eric Schnapper, Unreasonable Searches and Seizures of Papers, 71 VA. L. REv. 869 (1985).

283. Cf. Fisher v. United States, 425 U.S. 391, 401 n.7 (1976) (noting “[s]pecial problems of privacy which might be presented by subpoena of a personal diary").

284. See Henry E. Smith, Two Reliability Rationales for the Privilege Against Self-Incrimination (Mar. 1995) (unpublished manuscript, on file with authors) (proposing "communicative" reliability rationale based on concern about risk of misunderstanding, and applying rationale to case of diaries).

285. See supra text accompanying notes 142-44. 


\section{E. The Big Idea(s)}

The Self-Incrimination Clause has long been a mandate in search of a meaning, and the scope of immunity permitted under it has varied widely over the centuries. The rule of testimonial immunity has powerful advantages, especially when compared with transactional and use plus use-fruits immunity. It safeguards defendants and emphasizes truth-finding.

How, one might ask, is such a positive-sum solution - reducing the risk of both false convictions and false acquittals - even possible? As statisticians have long understood, one can simultaneously reduce both false negatives and false positives only by bringing more information into a system. That is precisely what our proposal does - by bringing in fruit and facilitating civilized pretrial questioning. Our current system throws out too much information, and in the end, this hurts both truth-seeking prosecutors and innocent defendants.

But why does it make sense for the Self-Incrimination Clause to distinguish between compelled testimony and compelled fruit?

First and foremost, fruits and physical evidence are more reliable than coerced testimony itself. ${ }^{286}$ This analysis is similar to the logic underlying the substantive criminal law doctrine of corpus delicti. Truth is a preeminent criminal procedure value in the Bill of Rights: most procedures were designed to protect innocent defendants from erroneous conviction. ${ }^{287}$ Especially when pressured, people may confess - or seem to confess - to crimes they did not commit. As Blackstone put the point in his bestselling Commentaries, out-of-court confessions "are the weakest and most suspicious of all testimony; ever liable to be obtained by artifice, false hopes, promises of favor or menaces; seldom remembered accurately, or reported with due precision; and incapable in their nature of being disproved by other negative evidence."288 A leading modern com-

286. Cf. Friendly, supra note 63 , at 712 n.176 (observing that physical leads are often more important to law enforcement than getting statements for use in court). Because of huge leaps in technology, physical evidence can yield far more reliable information today than at the Founding. This enhanced reliability only strengthens the wisdom of respecting the testimony-fruits distinction established as early as 1783. See supra text accompanying notes 262-67. "Fruit" in our model of course also encompasses reliable third party testimony.

287. See supra note 151.

288. 4 BLACKSTONE, supra note 10 , at *357. Blackstone, always infiuential, is particularly important in this context because of the paucity of legislative history concerning the SelfIncrimination Clause at the ratification of the Bill of Rights. He retained an enormous legal influence at the time the Fourteenth Amendment was ratified. Note how Blackstone's emphasis on reliability parallels the analysis in the 1783 case of The King v. Warickshall, 168 Eng. Rep. 234 (K.B. 1783), discussed supra section II.D. See also BARLow, supra note 154, at 189 (claiming that using "the Rack or Torture to compel Criminals to accuse themselves" is 
mentator, Judge Friendly, echoed Blackstone's concern and noted that the main motivation behind extending the privilege to informal proceedings must have been "the truly dreadful risk of the false confession.... [T] here is thus good reason to impose a higher standard on the police before allowing them to use a confession of murder than a weapon bearing the confessor's fingerprints to which his confession has led ...."289

Though the prospect of an unreliable confession (or perceived confession) occurring on the witness stand itself may seem to some unlikely in a criminal trial today, we must remember that from 1789 until well into this century, many innocent defendants in noncapital cases could not afford lawyers and were not furnished lawyers by the government. If forced to take the stand, they might be bullied or bamboozled by a professional prosecutor into assenting to untrue or misleading propositions that would - wrongly - seal their fate in the minds of the jury. While the concern about a slip-up on the stand applies to other witnesses as well, slip-ups by the defendant are particularly damaging in jurors' minds. ${ }^{290}$

In a post-Gideon ${ }^{291}$ world the defenseless defendant scenario is less likely, but even after Gideon, many defendants enjoy only nominal assistance of counsel. Moreover, even a good lawyer cannot always save an innocent but unpersuasive-sounding client from being demolished on the stand. As the Supreme Court observed a century ago in one of its earliest self-incrimination opinions:

It is not every one who can safely venture on the witness stand though entirely innocent of the charge against him. Excessive timidity, nervousness when facing others and attempting to explain transactions of a suspicious character, and offenses charged against him, will often confuse and embarrass him to such a degree as to increase rather than remove prejudices against him. It is not every one, however honest, who would, therefore, willingly be placed on the witness stand. ${ }^{292}$

not only "cruel" but "at the same Time uncertain, as being rather Trials of the Strength and Hardiness of the Sufferer, than any Proof of the Truth"), quoted in Langbein, supra note 2, at 1085 n.157.

289. FRIENDLY, supra note 102, at 281-82.

290. Compare Blackstone's suggestion that statements from the defendant's own lips have a peculiarly devastating impact. See supra text accompanying note 288.

291. Gideon v. Wainwright, 372 U.S. 335 (1963) (establishing the right of indigent defendants in noncapital cases to have the assistance of appointed counsel).

292. Wilson v. United States, 149 U.S. 60, 66 (1893) (emphasis added). Note how these concerns are not present in the typical case where the government secretly wiretaps a suspect in his home and later introduces his words - his "testimony" - in open court against his will. Although noninstrumentalists might have a hard time distinguishing between using a defendant on the stand and using him in a wiretap, see supra note 161, a reliability approach shows why these two cases are different. 
More recently, the Supreme Court's repeated emphasis on trustworthiness has led it to sharpen the difference between testimony and physical evidence; the logical culmination of this trend is testimonial immunity. We need not say every coerced statement is unreliable, or every physical fact reliable; the Fifth Amendment lays down a bright-line rule, and as with any rule the rationale need not explain every instance of the rule's application. It is enough that as a category, a criminal defendant's compelled testimony is particularly troubling on reliability grounds. ${ }^{293}$ On the other hand, voluntary testimony is likely to be more reliable because innocent defendants have the opportunity to screen themselves on the basis of whether they might be misunderstood.

Focusing on reliability answers our three basic questions that any theory of the clause must confront. First, why does the privilege apply only in a "criminal case" and not in civil ones? The answer lies in the higher degree of certainty required for a criminal conviction. We insist on proof beyond a reasonable doubt in criminal but not civil cases precisely because we are so much more concerned about erroneous criminal convictions. For the same reason, we are particularly concerned with unreliable evidence being introduced against a criminal defendant. (This also helps explain why corpus delicti is a criminal doctrine. ${ }^{294}$ ) Second, why can immunity overcome the privilege and "compel" a witness to speak? Because the fruits, which can be introduced in a criminal trial, will be more reliable than the speaker's immunized words, which must be excluded. Finally, why does the Fifth Amendment concern "witnessing" rather than furnishing evidence? Again, pieces of physical evidence - a gun, the defendant's own body, tax records - are more reliable than forced words.

Although our approach begins with reliability, it does not end there. Government interrogation and investigation implicates other

293. Nor are reliability concerns always cured by a physical corroboration test, because many confessions may concern internal mental states, where misunderstandings are quite likely. In short, physical evidence can at best partially rather than fully corroborate a statement. To the extent the physical evidence partially corroborates, it can be introduced itself. To introduce the confession in addition risks introduction of unreliable and uncorroborated aspects of the confession - say, about the defendant's mens rea. Perhaps, however, the trier of fact could be told merely that "something defendant said" led the police to the victim's body, the stolen goods, or what have you. On the other hand, this paraphrase looks rather like defendant witnessing - it is an account of defendant's own words - and, as with all paraphrases, introduces reliability concerns of its own.

294. Under our reading, the Self-Incrimination Clause strongly harmonizes with the doctrine of corpus delicti. Both sharply distinguish, on reliability grounds, between a suspect's self-accusatory words on the one hand, and reliable physical fruit and third-party witnesses' reliable testimony, on the other. 
constitutional values, and our approach respects these values. For example, a distinction between testimony and physical evidence indirectly promotes First Amendment values. A rule excluding from criminal cases only defendants' compelled utterances (and perhaps intimate personal papers such as diaries) would lead to acquittals for most eighteenth-century thought crimes - including blasphemy, heresy, and sedition ${ }^{295}$ - but it would not be nearly so big a stumbling block to prosecution of murderers and rapists, whose crimes generate nontestimonial fruits like knives and bodies. 296 Thus we do justice to both the Fifth Amendment's literal application beyond the thought crime and to its obviously weaker intuitive appeal in cases of violent crime.

Related to the First Amendment freedoms of thought and conscience is a certain narrow but important protection of "mental privacy" and "noninstrumentalization." A criminal defendant's compelled utterances may often reveal interior mental states - of guilt, conscience, joy, and so on. These compelled words and thoughts may reflect a defendant's inner self - his soul - and are far more likely to emerge in criminal interrogation than in the typical civil case. Under our reading, government at trial may not directly use a person's compelled inner life as the means of that person's own destruction. The government may directly use only tangible things - fruits - typically focusing on what happened rather than the personal meaning the defendant wishes to attach to these events. In this limited but important sense, our reading protects a person from being compelled in a criminal case to be a witness against his own inner "self." The government is entitled to, and may use, every man's evidence, but not his soul. A straightforward focus on reliability reaches the same result. Reports of inte-

295. Thought crimes have not been confined to the eighteenth century. Persecution of thought crimes, especially political crimes, has continued to generate praise for a right to remain silent. The anti-Communist hearings and trials of the $1950 \mathrm{~s}$, for instance, provoked fervent defenses of the privilege, most notably from Erwin Griswold. See Griswold, supra note 32. For a more general discussion of how the Fourth and Fifth Amendments have been pressed into the service of First Amendment values, see Stuntz, supra note 115.

296. To fully protect mere "thought criminals," we need to supplement the Fifth Amendment with an absolute privilege of associational privacy for purely political and religious confederates, lest a person be compelled to divulge the identity of his thoughtmates who could then be forced to testify against him. Cf. Shelton v. Tucker, 364 U.S. 479 (1960) (holding that states cannot compel teachers to disclose their associational ties because to do so deprives teachers of their right to associational freedom); NAACP v. Alabama, 357 U.S. 449 (1958) (holding that a political association may assert its members' constitutional right not to be compelled to disclose their affiliation with the association). In the absence of this absolute privilege, testimonial immunity could not protect a political or religious group very well. But neither could Counselman or Kastigar: one person with immunity could be obliged to furnish a list of members, and each member could then be obliged to testify against each other. 
rior mental states are easily misunderstood, notoriously imprecise (depending on a person's mood when reporting), and hard to verify. "How did you feel when you killed her?" is a very different kind of question from "Where is her body buried?"

The "psychological cruelty" of a compelled self-incrimination now appears in a very different light. Conventional accounts focused on guilty defendants faced with a "cruel" choice of contempt, self-accusation, or perjury. Earlier, we rejected this misplaced effort to shield evildoers from the consequences of their crimes. But once we see that compelled testimony from an innocent defendant may be misleading, and may destroy a man who has done no wrong, a different cruelty emerges: the cruelty of forcing someone who knows he is innocent but unpersuasive to take the stand, knowing that his truthful testimony may well hang him because a clever prosecutor can twist his words, and make him look guilty before the jury. A desire to protect the innocent defendant from erroneous conviction - and from the added injury, insult, and cruelty of being forced to cut his own throat with an honest but unpersuasive performance - is wholly consistent with the deep structure of our Bill of Rights.

An added advantage of our approach is that no "emergency exception" is needed to prevent imminent harm. The need to get fruits in emergency situations - a loaded gun in Quarles ${ }^{297}$ or Innis, ${ }^{298}$ or a child in Bouknight ${ }^{299}$ or Brewer ${ }^{300}$ - will not create an exception that impermissibly allows compelled testimony itself to be introduced at trial. Justice O'Connor wisely warned against creating a "finespun new doctrine on public safety exigencies incident to custodial interrogation, complete with the hair-splitting distinctions that currently plague our Fourth Amendment jurisprudence."301

Finally, the use of depositions and pretrial judicial examination would curb the temptation to police abuse. Questioning would be accomplished in a relatively civilized setting, as in civil litigation, rather than in the rough-and-tumble atmosphere of interrogation at the police station, with its attendant intimidation, sleeplessness, and other physical and psychological pressures. The process would be judicially supervised; refusals to answer and outright lies would be

297. New York v. Quarles, 467 U.S. 649 (1984).

298. Rhode Island v. Innis, 446 U.S. 291 (1980).

299. Baltimore City Dept. of Social Servs. v. Bouknight, 493 U.S. 549 (1990).

300. Brewer v. Williams, 430 U.S. 387 (1977).

301. Quarles, 467 U.S. at 663-64 (O'Connor, J., concurring in part and dissenting in part). 
punished with judicial contempt or adverse inferences, ${ }^{302}$ not with fists banging on desks and shouted four-letter words. These depositions and hearings would act as the equivalent of the nineteenthcentury questioning of the accused by a magistrate. Fourth Amendment standards would constrain both the government's right to demand answers in general - the government must justify its decision to single a person out for detention (seizure) and interrogation (search) - and the government's right to ask any particular question. Irrelevant questions, questions for which no foundation had been laid, intrusive or embarrassing questions, repetitive questions - all these should be subject to a general Fourth Amendment test of reasonableness. ${ }^{303}$

The Founding-era history of the self-incrimination slogan in America was bound up with concerns about torture, and our solution attacks the problem of torture on several fronts. While torture can be lawless and unregulated, leaving a suspect's body and mind subject to the whims of examiners, our approach civilizes and controls the process of evidence-gathering. While torture produces unreliable confessions, our approach emphasizes reliability. While torture is cruel, we provide a check by focusing on unreasonable or intrusive Fourth Amendment seizures of the person. (And the fact that even criminal witnesses and civil witnesses and parties - and everyone else, too - must be protected against torture proves that the root antitorture idea is largely a Fourth Amendment idea and not a Fifth Amendment idea.) Finally, torture has at times been particularly likely to occur in cases involving religious and political opponents of the government. In response, we stress the First Amendment values protected when a defendant's words cannot be introduced at trial.

\section{CONCluSion}

While our approach may at first glance seem like a startling break from current interpretations, in fact it is merely an extension of any one of four current doctrines or trends. First, it is a logical extension of Schmerber's ${ }^{304}$ distinction between physical evidence

302. See supra text accompanying notes 190-91.

303. Eben Moglen quotes a Boston pamphlet from 1769 attacking ex officio oaths as inviting customs commissioners in Vice Admiralty courts to harass their political opponents with vexatious, impertinent, and groundless questions such as "Pray Sir, when did you kiss your maid Mary? - Where? and in what manner? .. . Did you lay with her in a barn? or in your house?" Moglen, supra note 184, at 1116 . On the obviously gendered nature of this example and of privacy discourse generally, see Amar, supra note **, at 808-09.

304. Schmerber v. California, 384 U.S. 757 (1966). 
and testimony. Second, the Court could replace Kastigar ${ }^{305}$ by following the same reasoning that it followed in Murphy306 as it moved toward replacing Counselman ${ }^{307}$ with Kastigar in the first place: intersovereign friction would be eliminated. Third, Justice O'Connor has pointed the way in Quarles, ${ }^{308}$ where she suggested always allowing fruits in for mere Miranda violations. And finally, an extension of the inevitable discovery doctrine would simply presume that fruits have an independent source and thus can be introduced at trial.

Fifth Amendment jurisprudence, like that of the Fourth Amendment, needs to regain coherence. In Fourth Amendment case law, Boyd's ${ }^{309}$ (con)fusion of the Fourth and Fifth Amendments led to a constitutionally flawed exclusionary rule, motivated by the mistaken notion that the Fourth, like the Fifth, requires that certain items be excluded from a criminal case. ${ }^{310}$ In Fifth Amendment case law, Boyd's (con)fusion has led to the mistaken notion that the Fifth, like the Fourth, is about things - "effects" or fruits - and not just words. Instead, the privilege requires immunity that is absolute but narrow. Fact gathering should be accomplished under circumstances that are both more civilized and more apt to produce the truth. Instead of the current wide divergence between civil and criminal discovery practice, the two should be brought closer together. Finders of fact in criminal cases should not be deprived of reliable, highly probative evidence. A legal system that ignores the truth is simply not doing its job, and neither is a court that cannot make the Constitution cohere.

305. Kastigar v. United States, 406 U.S. 441 (1972).

306. Murphy v. Waterfront Commn., 378 U.S. 52 (1964).

307. Counselman v. Hitchcock, 142 U.S. 547 (1892).

308. New York v. Quarles, 467 U.S. 649, 660-74 (1984) (O'Connor, J., concurring in part and dissenting in part).

309. Boyd v. United States, 116 U.S. 616 (1886).

310. See Amar, supra note **, at 787-91. For a long list of cases documenting that the socalled Fourth Amendment exclusionary rule was really a joint Fourth-Fifth affair, under a theory that the Court has now rightly discredited, see Amar \& Marcus, supra note 69, at 16 n.97. In addition to the eleven U.S. Supreme Court cases cited there, see also Adams v. New York, 192 U.S. 585, 594, $597-98$ (1904); Perlman v. United States, 247 U.S. 7, 13 (1918); Burdeau v. McDowell, 256 U.S. 465, 474-76 (1921); Marron v. United States, 275 U.S. 192, 194 (1922); United States v. Lefkowitz, 285 U.S. 452, 466-67 (1932); and Ker v. California, 374 U.S. 23, 30 (1963). See generally Corwin, supra note 177, at 1-2, 13-16, 203-04 (carefully reading exclusionary case law as based on a Fourth-Fifth fusion). 